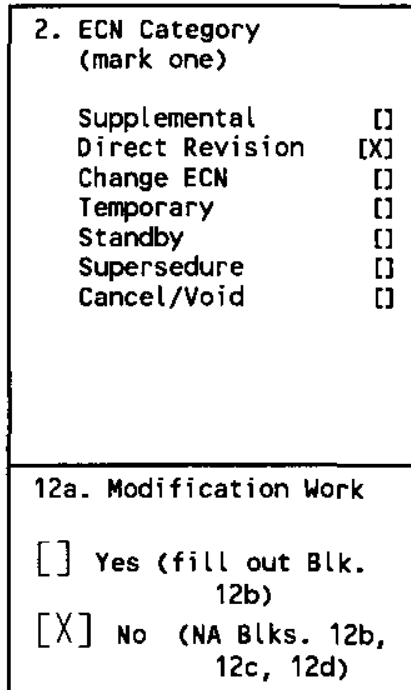

13a. Description of Change Complete revision.
3. Originator's Name, Organization, MSIN, and Telephone No.

Charles H. Mulkey,

Environmental Permits/Policy, R1-51, 373-0956

6. Project Title/No./Work Order No.

Data Quality Objectives for Regulatory Requirements

9. Document Numbers Changed by this ECN (includes sheet no. and rev.) WHC-SD-WM-DQO-025, Rev. 0

12b. Work Package $12 \mathrm{c}$. Modification Work Complete No.

$N / A$

$$
N / A
$$
4. USQ Required?
[] Yes $[X]$ No

7. Bldg./Sys./Fac. No.

$N / A$

10. Related ECN No(s).

N/A

5. Date

$06 / 30 / 99$

8. Approval Designator

E, Q

11. Related PO No.

$N / A$

12d. Restored to Original Condition (Temp. or Standby ECN only) $\mathrm{N} / \mathrm{A}$

Design Authority/Cog. Engineer Signature \& Date

13b. Design Baseline Document? Signature \& Date

Design Authority/Cog. Engineer

[] Yes $[X]$ No

14a. Justification (mark one)

Criteria Change $[X]$ Design Improvement [] Environmental [] Facility Deactivation []

As-Found [] Facilitate Const [] Const. Error/Omission [] Design Error/Omission []

14b. Justification Details

Clarification and update of regulatory requirements.

15. Distribution (include name, MSIN, and no. of copies) See attached distribution. 


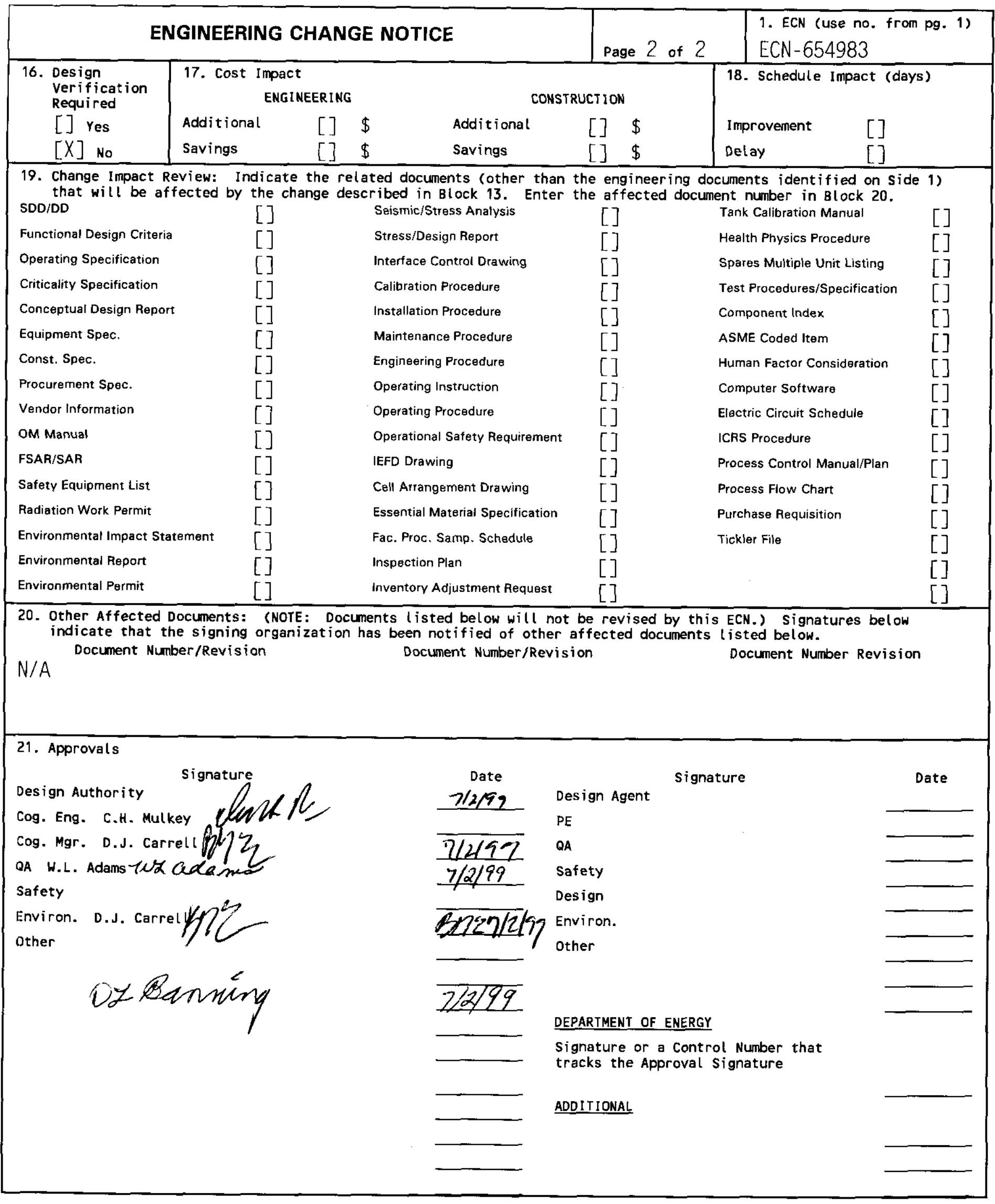




\section{Data Quality Objectives for Regulatory Requirements for Dangerous Waste Sampling and Analysis}

Charles L. Mulkey

Lockheed Martin Hanford, Corp., Richland, WA 99352

U.S. Department of Energy Contract DE-AC06-96RL13200

$\begin{array}{lll}\text { EDT/ECN: } & \text { ECN }-654983 & \text { UC: } 2070 \\ \text { Org COde: } & 7 B 200 & \text { CACN/COA: 102211/EI00 } \\ \text { B\&R Code: } & \text { EW } 3120074 & \text { Total Pages: } 52\end{array}$

Key Words: Data Quality Objectives, DQO, Regulatory Requirements, Regulatory, Dangerous, Waste, Sampling, Analysis

Abstract: N/A

TRADEMARK DISCLAIMER. Reference herein to any specific comercial product, process, or service by trade name, trademark, manufacturer, or otherwise, does not necessarily constitute or imply its endorsement, recommendation, or favoring by the United States Government or any agency thereof or its contractors or subcontractors.

Printed in the United States of America. To obtain copies of this document, contact: Document Control Services, P.0. Box 950, Mailstop H6-08, Richland WA 99352, Phone (509) 372-2420; Fax (509) 376-4989.
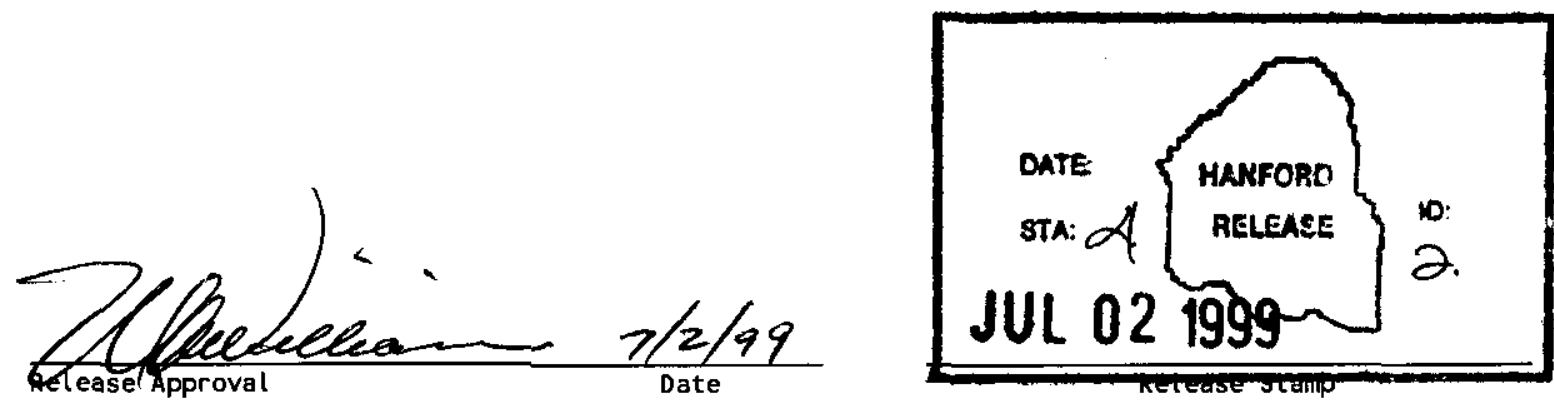

Approved for Public Release 


\section{RECORD OF REVISION}

(2) Title

Data Quality Objectives for Regulatory Requirements for Dangerous Waste Sampling and Analysis

CHANGE CONTROL RECORD

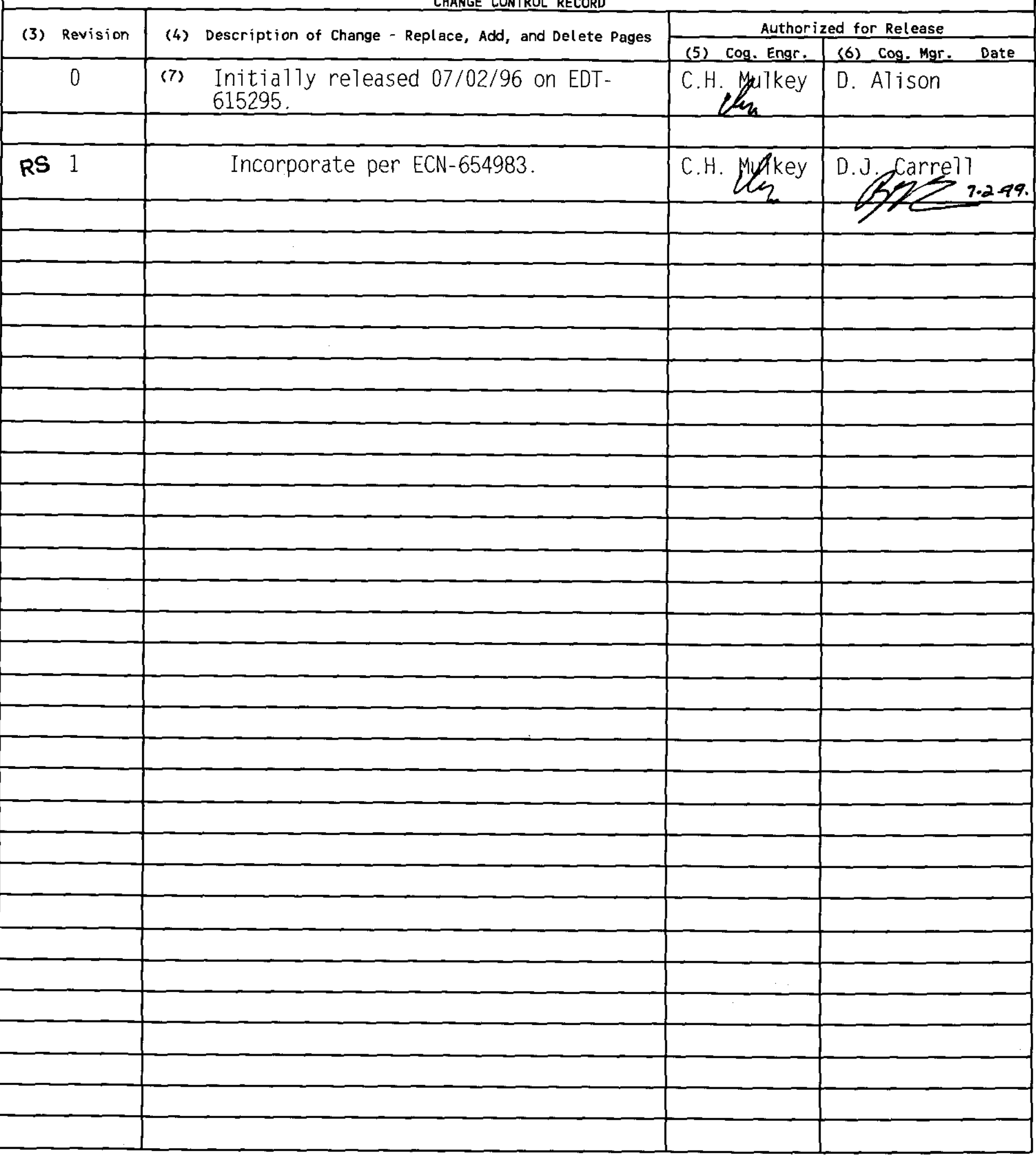




\title{
Data Quality Objectives for Regulatory Requirements for Dangerous Waste Sampling and Analysis
}

\author{
Charles H. Mulkey
}

Lockheed Martin Hanford Corporation

Date Published

June 1999

Prepared for the U. S. Department of Energy

Assistant Secretary for Environmental Management

Project Hanford Management Contractor for the

U.S. Department of Energy under Contract DE-AC06-96RL13200

Approved for Public Release; Further Dissemination Unlimited 
HNF-SD-WM-DQO-025 Rev. 1

This page intentionally left blank. 
HNF-SD-WM-DQO-025 Rev. 1

\section{EXECUTIVE SUMMARY}

The Data Quality Objective Process was conducted to identify the regulatory drivers for sampling and analysis of River Protection Project facilities to characterize the wastes managed by the River Protection Project. The River Protection Project is responsible primarily for the storage of waste in the tank farms; waste treatment and disposal will be addressed under a separate contract through the U.S. Department of Energy, Richland Operations Office. The wastes include the contents of single- and double-shell tanks, inactive miscellaneous underground storage tanks, and new wastes sent to the Hanford Tank Farms, as well as secondary wastes generated through the management of these materials. Previous sampling has indicated that there are toxic and hazardous materials present in the tanks.

Both Federal and State regulatory programs govern the management of the tank waste. Federal regulations for hazardous waste are found under the Resource Conservation and Recovery Act of 1976 at 40 CFR 260 et seq., while the Washington State Dangerous Waste regulations are found in Washington Administrative Code 173-303. The State regulations incorporate the Federal program requirements, along with additional restrictions. Regulations that govern the radionuclide portion of the wastes are found elsewhere and are not addressed through this Data Quality Objective process. Dangerous waste regulations require the generators of wastes to characterize their waste through either process or analytical knowledge. The Data Quality Objective Process was used to identify regulatory drivers for specific analytical needs and action levels for specific analytes (see Table 6-1). The Data Quality Objective process also establishes the universe of facilities for which this process is to be applied. 
Section 6.0 contains the decision rules, which describe the consequences if analyses indicate the presence of constituents in the tank contents at levels that exceed the relevant action levels. These include the potential application of additional regulatory program requirements, along with the appropriate handling requirements for the newly defined category(ies). Section 7.0 describes the methods that will be used to evaluate the results of data analyses. Section 8.0 presents the recommended approach for sample collection and analysis, including the number of samples, analytical methods, and recommendations for analytical and field quality control. 


\section{TABLE OF CONTENTS}

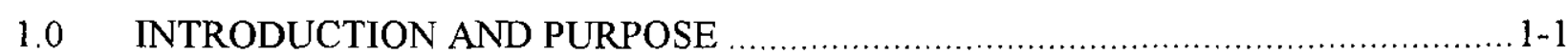

1.1 DATA QUALITY OBJECTIVES ........................................................

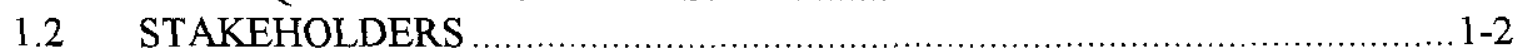

1.3 APPROACH TO ANALYTE SELECTION AND ANALYSIS ….................1-2

1.4 APPLICABILITY AND SCOPE ….....................................................

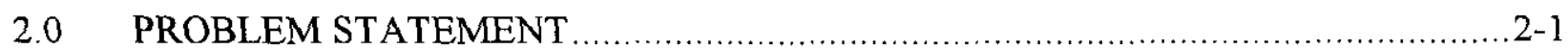

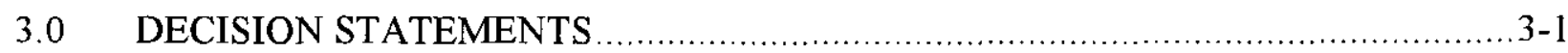

3.1 GENERATOR REQUIREMENTS (WAC 173-303) ..................................

3.2 INTERIM TREATMENT AND STORAGE (WAC 173-303) …....................

3.3 FINAL TREATMENT AND DISPOSAL (WAC 173-303) ….......................

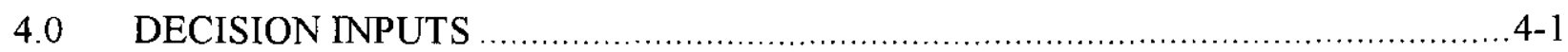

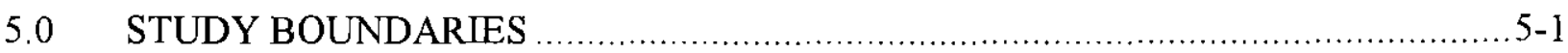

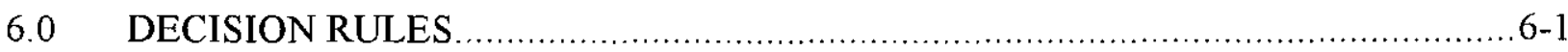

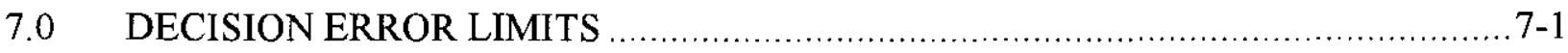

8.0 OPTIMIZATION OF SAMPLING AND ANALYSIS DESIGNS ……...................

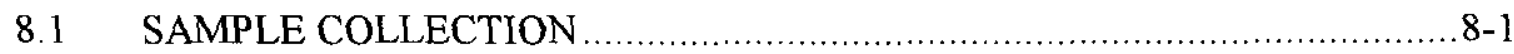

8.1.1 Number of Samples and Type of Collection ..................................... 8-2

8.1.2 Field Quality Control......................................................................

8.2 STORAGE, HOLDTIMES, PRESERVATION OF SAMPLES …..................8-4

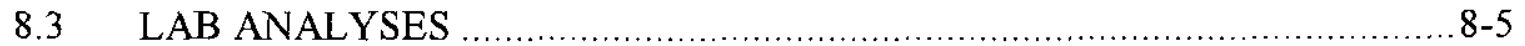

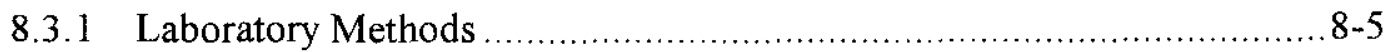

8.3.2 Lab Quality Control .................................................................... $8-8$

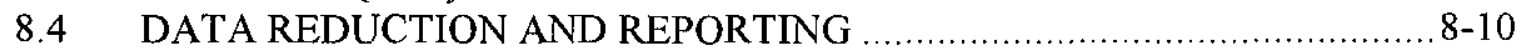

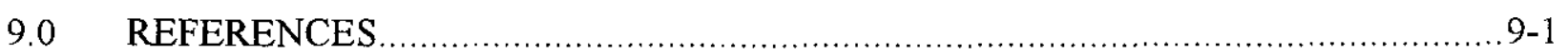




\section{LIST OF TABLES}

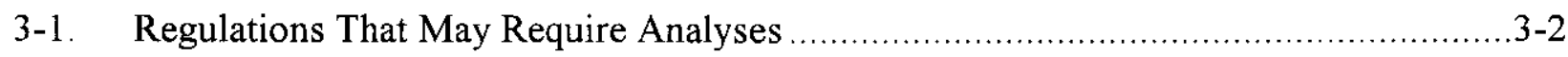

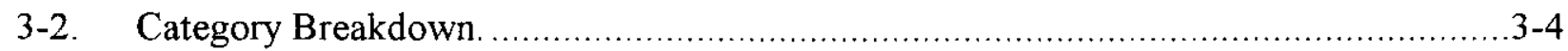

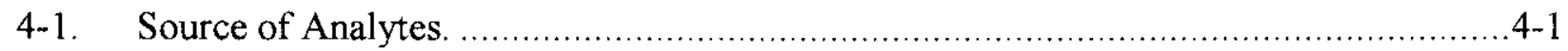

6-1. Action Limit as Specified by Regulatory Drivers ..........................................6-1

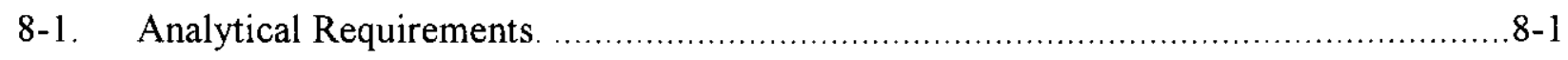

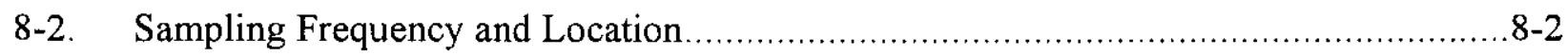

8-3. Field Quality Control Sample Type and Frequency....................................... $8-4$

8-4. Storage and Preservation Listed in SW-846 Versus the Actual Conditions Proposed. ...8-6

8-5. Dangerous Waste COPC Analytical Requirements ....................................... 8-7

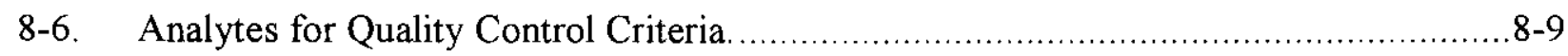

8-7. Lab Quality Control Sample Type and Frequency .......................................... 8-10

\section{APPENDIX}

A REGULATIONS THAT MAY REQUIRE ANALYSES ................................. A-i 
HNF-SD-WM-DQO-025 Rev. 1

\section{LIST OF TERMS}

CAS \# chemical abstract services number

CERCLA Comprehensive Environmental Response, Compensation, and Liability

CFR Act of 1980

COPC

Code of Federal Regulations
constituent of potential concern

CWC

DCRT

DQO

DST

DW

Ecology

EPA

IMUST

ISE

Central Waste Complex

double-contained receiver tank

Data Quality Objective

double-shell tank

dangerous waste

Washington State Department of Ecology

U.S. Environmental Protection Agency

inactive miscellaneous underground storage tank

LCS

LDR

ion-selective electrode

laboratory control sample

Land Disposal Restriction

MS

matrix spike

MSD

N/A

PCB

PQL

QA

QC

matrix spike duplicate

not applicable

polychlorinated biphenyl

practical quantitation limit

quality assurance

quality control

RCRA

RPD

RPP

SST

TSCA

Resource Conservation and Recovery Act of 1976

relative percent difference

River Protection Project

single-shell tank

Toxic Substances Control Act

WAC

Washington Administrative Code

WSPS

waste stream profile sheets 


\section{GLOSSARY}

Dangerous Waste (DW). Those solid wastes designated in Washington Administrative Code (WAC) 173-303-070 through 173-303-100 as dangerous, extremely hazardous, or mixed waste (WAC 173-303-040 provides the definitions). May also be defined as hazardous in accordance with 40 Code of Federal Regulations (CFR) 261.3.

Designate. The act of determining and assigning the DW and hazardous waste codes to a waste. See WAC 173-303-070 for the designation of DW.

Driver. A rule or regulation which contains a requirement for which analytical data are required or for which analytical data should be obtained.

Interim Treatment. Treatment of a waste for reasons other than for satisfying a land disposal requirement. An example is the treatment in double-shell tanks to meet corrosion control parameters.

Monitor. An ongoing program used to sample and report the concentration of contaminants contained in an effluent stream and designed to account for variations in the processes or operations that generate the effluents.

Release. Any spilling, leaking, pumping, pouring, emitting, emptying, discharging, injecting, escaping, leaching, dumping, or disposing into the environment (including the abandonment or discarding of barrels, containers, and other closed receptacles) of any toxic chemical. (40 CFR 372.3) waste.

Secondary Waste. Waste, which is produced as the result of handling, treating, or storing

Type I Error. This error occurs when data mislead a decision maker into believing that the burden of proof in a hypothesis has been satisfied, to that the null hypothesis is erroneously rejected (also called alpha error). For this project, the hypothesis is that the action levels are exceeded. A Type I Error is determining that the hazardous/DW/land disposal restriction (LDR) limits are not exceeded when the limits have actually been exceeded (EPA 1994).

Type II Error. This error occurs when data mislead a decision maker into wrongly concluding that the burden of proof in a hypothesis test has not been satisfied so that the null hypothesis is accepted (also called beta error). For this project, the hypothesis is that the action levels are exceeded. A Type II Error is determining that the hazardous/DW/LDR limits are exceeded when the limits have actually not been exceeded (EPA 1994).

Waste Analysis Plan. The plan for waste analysis which meets the requirements in WAC 173-303-300. 
HNF-SD-WM-DQO-025 Rev. 1

\subsection{INTRODUCTION AND PURPOSE}

This document describes sampling and analytical requirements needed to meet state and federal regulations for dangerous waste (DW). The River Protection Project (RPP) is assigned to the task of storage and interim treatment of hazardous waste. Any final treatment or disposal operations, as well as requirements under the land disposal restrictions (LDRs), fall in the jurisdiction of another Hanford organization and are not part of this scope. The requirements for this Data Quality Objective (DQO) Process were developed using the RPP Data Quality Objective Procedure (Banning 1996), which is based on the U.S. Environmental Protection Agency's (EPA) Guidance for the Data Quality Objectives Process (EPA 1994). Hereafter, this document is referred to as the DW DQO.

Federal and state laws and regulations pertaining to waste contain requirements that are dependent upon the composition of the waste stream. These regulatory drivers require that pertinent information be obtained. For many requirements, documented process knowledge of a waste composition can be used instead of analytical data to characterize or designate a waste. When process knowledge alone is used to characterize a waste, it is a best management practice to validate the information with analytical measurements.

\subsection{DATA QUALITY OBJECTIVES}

The purpose of this DW DQO is to identify data needs for complying with regulatory drivers for the sampling and analysis of DW managed in or generated at RPP facilities. These drivers include both specific regulatory requirements and best management practices. (Note: analyses may have more than one regulatory driver associated with them). Data needs include sampling requirements for both radionuclide and nonradionuclide analytes from facility DW materials. Radionuclides are not regulated under the Resource Conservation and Recovery Act of 1976 (RCRA) or the Washington Dangerous Waste regulations and, therefore, are not addressed in this document. The analyses required by this document need to be incorporated into the sampling and analytical plans for RPP facilities.

Pertinent federal and state regulations were reviewed and those which may result in a data need are listed in Table 3-1. Table 3-1 contains a short description of the regulatory driver and the need to obtain additional data. Appendix A provides a list of regulations that presently drive the collection of additional data. Both Table 3-1 and Appendix A include the rationale for the decision to either require or not require additional analysis. The applicability of these requirements is based on current RPP activities. Changes in RPP activities or regulatory requirements may result in a need to modify these requirements, at which time the DQO would be amended. 


\subsection{STAKEHOLDERS}

The major programs that might be impacted by the results of this DQO are the East and West Tank Farm Projects, the Environmental Cleanup and Compliance Project, and the Characterization Project.

\subsection{APPROACH TO ANALYTE SELECTION AND ANALYSIS}

The regulatory drivers serve as the basis for the analyte selection process as outlined in Section 4.0. A listing of required analyses is contained in Section 8.0, Tables 8-5 and 8-6. Regulatory requirements are expected to change as permits are issued and regulations are modified. Therefore, this document should not be used to determine overall compliance with Dangerous Waste Regulations as they are in constant change.

\subsection{APPLICABILITY AND SCOPE}

The applicability of this document includes all equipment, facilities and operations under the jurisdiction of RPP, which generate or handle DW as defined by Washington Administrative Code (WAC) 173-303-040 (see Glossary). The scope, as related to double-shell tanks (DSTs), single-shell tanks (SSTs), and inactive miscellaneous underground storage tanks (IMUSTs), includes:

- interim treatment, such as addition of hydroxide to raise $\mathrm{pH}$ and prevent corrosion of the tank and includes storage

- evaluation of waste being sent to the DSTs

- double-contained receiver tanks (DCRTs) that are in the Tank Farm system and temporarily hold waste as the waste is transferred between tanks

- RPP-generated secondary waste sent to the Central Waste Complex (CWC) or other facilities.

The scope does not include final treatment being managed by British Nuclear Fuels Limited and final storage of vitrified waste. Table 8-1 lists analytical requirements for specified equipment. 


\subsection{PROBLEM STATEMENT}

This DW DQO identifies sampling and analysis requirements for the RPP facilities which are needed to address environmental regulatory needs. The RPP handles or is responsible for the storage of hazardous waste in SSTs and DSTs at the Hanford Site. Previous sampling has indicated the presence of toxic and hazardous constituents in the SSTs and DSTs, as well as the waste processing facilities. Compliance with regulatory requirements may require additional analysis. These analytical requirements may not be adequately addressed by existing programs and could lead to impacts on compliance with the various environmental regulations (drivers). 
HNF-SD-WM-DQO-025 Rev. 1

This page intentionally left blank. 
HNF-SD-WM-DQO-025 Rev. 1

\subsection{DECISION STATEMENTS}

As established in Section 2.0, the characterization efforts to perform and maintain compliance with regulations for DW at RPP facilities need to be specified. This document will help ensure such compliance and addresses three key questions:

1. Why are data required?

2. What data are required?

3. How should these data be obtained?

Because the scope of this document is limited to regulatory drivers, all data requirements must be related to a regulatory requirement. State and federal regulations governing dangerous (hazardous) waste were reviewed to determine if they contained potential drivers for analysis. Table 3-1 contains a listing of the regulatory drivers that were identified as a possible basis for analysis. Also included in Table 3-1 is a decision on whether or not this DW DQO needs to address the driver and a brief rationale for this decision. Table 3-2 uses the drivers listed in Table 3-1 and groups them into categories of generator, storage and interim treatment, and final treatment and disposal. These categories are described in the following sections. As an aid to modifications to this document, the drivers which do not presently require analysis are maintained in Appendix A to keep the requirements documented for future reference when operations change or if other programs do not adequately address the requirements.

\subsection{GENERATOR REQUIREMENTS (WAC 173-303)}

The regulations in WAC 173-303 for waste generators include by reference the federal regulations from 40 Code of Federal Regulations (CFR) 261 (waste designation), 40 CFR 262 (requirements for generators of hazardous waste), 40 CFR 268 (LDR) and 40 CFR 750 and 761 (Toxic Substances Control Act [TSCA]). The Washington State waste regulations require that waste generators properly designate their waste. Waste designation is accomplished by determining if the waste displays a hazardous characteristic and by determining if the waste originated from a specific source. Characteristic determination can be based on either process knowledge or actual analysis. For TSCA, it might be necessary to analyze the waste matrices separately for their polychlorinated biphenyl (PCB) content. This waste designation is then used to establish disposal requirements for the waste and to specify any treatment that is required prior to disposal. 
HNF-SD-WM-DQO-025 Rev. 1

Table 3-1. Regulations That May Require Analyses. (2 Sheets)*

\begin{tabular}{|c|c|c|c|c|}
\hline Item & Regulatory oriver & 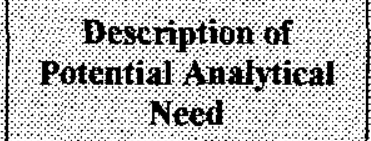 & Madritional & Rationsto \\
\hline 1 & $\begin{array}{l}\text { WAC } 173-303-071(3)(\mathrm{k}) \\
40 \text { CFR } 268.32 \\
40 \text { CFR } 750 \text { and } 761 \\
\text { (TSCA) }\end{array}$ & $\begin{array}{l}\text { Identification of specific } \\
\text { exemptions relating to } \\
\text { PCBs }\end{array}$ & Yes & $\begin{array}{l}\text { Some analysis may be necessary to determine if the waste can be exempted from } \\
\text { regulation under this section. Analyses that may be needed inciude those necessary for } \\
\text { waste designation and/or PCB concentration. }\end{array}$ \\
\hline 2 & WAC 173-303-100(5) & Toxicity Criteria & $\begin{array}{l}\text { Possible due to } \\
\text { unknown tank } \\
\text { contents of } \\
\text { IMUSTs. Analysis } \\
\text { may be required. }\end{array}$ & $\begin{array}{l}\text { A determination needs to be made as to whether or not the waste qualifies as a toxic } \\
\text { waste. This can be accomplished either by book designation or by analysis. The waste } \\
\text { in the tanks has already been designated, but secondary waste (derived from tanks) has } \\
\text { not. Analysis of tank waste would be useful for book designation of this newly } \\
\text { generated waste. }\end{array}$ \\
\hline 3 & WAC 173-303-100(6) & Persistence Criteria & Yes & $\begin{array}{l}\text { A determination needs to be made as to whether or not a waste contains halogenated } \\
\text { hydrocarbons and/or polycyclic aromatic hydrocarbons. This information is used in } \\
\text { assigning waste codes that are specific to Washington State. This information would } \\
\text { also be useful when designating secondary wastes. }\end{array}$ \\
\hline 4 & $\begin{array}{l}\text { WAC } 173-303-170 \\
\text { WAC } 173-303-300(2) \\
\text { WAC } 173-303-070 \\
40 \text { CFR } 261\end{array}$ & $\begin{array}{l}\text { Waste designation } \\
\text { and/or confirmation of } \\
\text { designation of waste } \\
\text { already in RPP }\end{array}$ & Yes & $\begin{array}{l}\text { The waste in the tanks has been designated using process knowledge. Confirmation of } \\
\text { designation is of limited value for tracking waste codes applicable in specific tanks due } \\
\text { to transfers and commingling of waste. Confirmation of designation does have value in } \\
\text { designating secondary waste and in obtaining a basis to review the initial conservative } \\
\text { designation. Confirmation of designation could result in the eventual removal of waste } \\
\text { codes from some or all of the SSTs and DSTs. }\end{array}$ \\
\hline 5 & WAC 173-303-400 (3)(a) & $\begin{array}{l}\text { Requirements in } 40 \text { CFR } \\
265 \text {, Subparts F to R, } \\
\text { Subpart W, Subparts } \\
\text { AA, BB, and DD }\end{array}$ & $\begin{array}{l}\text { See separate } \\
\text { responses for each } \\
\text { of these sections in } \\
\text { this table and } \\
\text { Appendix A }\end{array}$ & Washington State requirements incorporate the federal requirements by reference. \\
\hline 6 & WAC 173-303-640(7) & $\begin{array}{l}\text { Response to leaking } \\
\text { tanks }\end{array}$ & Yes & $\begin{array}{l}\text { In the event of a leaking tank, it may be necessary to conduct analyses to determine the } \\
\text { extent of the release and to document cleanup of the spill. Analyses may also be } \\
\text { required for the designation of any secondary waste that is produced from the response } \\
\text { actions. See WAC 173-303-646 (2)(a). }\end{array}$ \\
\hline
\end{tabular}


HNF-SD-WM-DQO-025 Rev. 1

Table 3-1. Regulations That May Require Analyses. (2 Sheets)*

\begin{tabular}{|c|c|c|c|c|}
\hline trem & Regurator s Bry & Potential & : & Rationate \\
\hline 7 & WAC $173-303-646(2)(a)$ & $\begin{array}{l}\text { Corrective action for } \\
\text { releases of DW and } \\
\text { dangerous constituents }\end{array}$ & Possibly & $\begin{array}{l}\text { Analytical requirements associated with releases would be very incident-specific; } \\
\text { therefore, no specific set of analytes can be specified in this document. In general, for } \\
\text { new spills the removal of the contaminated area as determined by visual observation and } \\
\text { radiation measurement is sufficient. Old spills are being cleaned up according to } \\
\text { CERCLA or RCRA past-practice requirements. Activities may need some analyses in } \\
\text { order to document that there has been sufficient cleanup. }\end{array}$ \\
\hline 8 & $\begin{array}{l}40 \text { CFR } 265.1050, \\
\text { Subpart BB }\end{array}$ & Equipment leaks & Possibly & $\begin{array}{l}\text { Requires analysis unless existing data and/or process knowledge indicate waste contains } \\
\text { less than } 10 \% \text { organics. Determination of the total organic content is needed in order to } \\
\text { document the applicability of the subpart. Determination can be made by waste analysis } \\
\text { or documented process knowledge. } 40 \text { CFR } 265.1063(\mathrm{~d})(3) \text {. Documentation of a waste } \\
\text { determination by knowledge is required. Examples of documentation that shall be used } \\
\text { to support a determination under this provision include production process information } \\
\text { documenting that no organic compounds are used, information that the waste is } \\
\text { generated by a process that is identical to a process at the same or another facility that } \\
\text { has previousiy been demonstrated by direct measurement to have a total organic content } \\
\text { less than } 10 \% \text {, or prior speciation analysis results on the same waste stream where it can } \\
\text { also be documented that no process changes have occurred since that analysis that could } \\
\text { affect the waste total organic concentration. }\end{array}$ \\
\hline 9 & 40 CFR 265, Subpart CC & $\begin{array}{l}\text { In support of air } \\
\text { emission regulation }\end{array}$ & Possibly & $\begin{array}{l}\text { Waste management units used solely for radioactive mixed waste in accordance with the } \\
\text { Atomic Energy Act of } 1954 \text { and the Nuclear Waste Policy Act of } 1982 \text { are excluded. If } \\
\text { waste is not mixed waste, determine volatile organic concentrations of liquid/solid waste } \\
\text { in support of air emissions either by analysis or documented process knowledge. }\end{array}$ \\
\hline 10 & $\begin{array}{l}\text { Hanford Site Solid Waste } \\
\text { Acceptance Criteria } \\
\text { (PHMC 1998) }\end{array}$ & $\begin{array}{l}\text { Acceptance of waste } \\
\text { sent to another facility }\end{array}$ & Yes & $\begin{array}{l}\text { In order to send a waste to another facility for final treatment or disposal, the waste } \\
\text { acceptance criteria for the receiving facility must be met to assure the waste is only sent } \\
\text { to facilities that can properly handle the waste. A portion of RPP's waste is sent to the } \\
\text { CWC. RPP's secondary waste, which is sent to the CWC, must meet the acceptance } \\
\text { criteria specified by PHMC (1998). Therefore, it becomes obligatory to meet these } \\
\text { requirements. }\end{array}$ \\
\hline
\end{tabular}

*Appendix A provides more information on regulatory drivers

CERCLA $=$ Comprehensive Environmental Response, Compensation, and Liability Act of 1980 
HNF-SD-WM-DQO-025 Rev. 1

Table 3-2. Category Breakdown.

\begin{tabular}{|c|c|}
\hline Category & len " from Trble 3 I \\
\hline Generator & $1,2,3,4,9,10$ \\
\hline Storage and Interim Treatment & $4,5,6,7,8,9$ \\
\hline Final Treatment and Disposal & 10 \\
\hline
\end{tabular}

Historically, waste received by RPP was designated by process knowledge. Legacy waste has been deemed to not meet LDR requirements, so the waste must be treated prior to land disposal. LDR requirements pertinent to waste received by DSTs are documented in the waste stream profile sheets (WSPS) which are required for all waste entering the DST system. Because there is no treatment in DSTs or SSTs to meet LDR requirements and the position has been taken that the waste must be further treated prior to land disposal, there is no regulatory requirement to test the waste for LDR constituents.

RPP activities also generate secondary waste. This waste primarily consists of contaminated equipment and clothing which has been in contact with tank waste. This secondary waste is usually transported to the CWC for burial and/or storage.

PCBs are regulated under TSCA. Tank farms do not accept TSCA waste. TCSA waste is defined as waste that contains $\geq 50 \mathrm{ppm}$ total PCBs per 40 CFR 761.3. EPA published in July of 1998 the Final Rule (Mega Rule) for PCB disposal. It allows for the actual measurement of PCB concentrations in waste. Remediation waste with concentrations of $\geq 2 \mathrm{ppb}$ PCBs might be TSCA-regulated waste. Laboratory waste can be TSCA-regulated if not exempt from regulation.

The Mega Rule includes provisions for multi-phasic PCB waste. The TSCA definitions of liquid and non-liquid PCBs are listed below:

- Liquid: Any liquid PCB waste that contains $>0.5 \%$ by weight of non-dissolved material must be analyzed as a multi-phasic non-liquid/liquid mixture. Concentrations of the liquid are reported on a wet weight basis.

- Non-liquid: Materials containing PCBs that by visual inspection do not flow at 25 degrees C or from which no liquid passes when a $200 \mathrm{~g}$ or $100 \mathrm{ml}$ representative sample is placed on a mesh number $60+/-5 \%$ paint filter and allowed to drain for five minutes. Concentrations are reported on a dry weight basis.

Based on past experience, it is expected that SST and DST waste will be multi-phasic. Waste generated by RPP for disposal must be evaluated to assess whether it is liquid or non-liquid. For equipment that is potentially contaminated with PCBs, the reader is referred to 40 CFR 761.3. For multi-phasic waste the following steps must be performed.

1. Determine the solid/sludge content visually or using the paint filter. 
2. Per the above definition, if the waste is multi-phasic, separate the phases.

3. Concentration for solids must be reported on a dry weight basis.

- The generator may report concentrations based on the highest PCB concentration in all phases, or

- The generator may analyze each phase separately and provide data on each phase.

\subsection{INTERIM TREATMENT AND STORAGE (WAC 173-303)}

Most analytical requirements which apply to the interim storage and treatment of waste are already specified in the DST Waste Analysis Plan (Mulkey 1998), and the SST Waste Analysis Plan (Mulkey 1996). These documents contain requirements pertaining to safe handling of waste and for waste acceptance. These documents do not specifically address analytical needs related to release reporting, response to leaks, and applicability of air emission controls.

Various regulations require reporting in the event of a release to the environment. This release can be continuous, intermittent, or a single event. Most of the regulations do not require that analyses be taken but do require reporting if certain quantities are emitted. In determining quantities, analytical information is often quite valuable and can help ensure proper reporting. The Air Regulatory DQO (Mulkey 1999) contains more information on this issue.

In the event of a suspected leak, it may be necessary to determine if the fluid found in the detection system is from the tank or the equipment. The best method of confirming whether or not the material in the detection system is from a tank leak is to compare analytical results of the fluid in the detection system with that of the fluid in the suspected source. If there is a close correlation between the two analyses, the leak could be considered confirmed. If the analyses do not match, the leak would remain unconfirmed and further investigation would be necessary. This same type of approach could be used for analyses of groundwater to determine if a particular source has resulted in groundwater contamination.

In recent years, the regulations (i.e., 40 CFR 265, Subpart BB and Subpart CC) have been amended to require air emission controls on waste processing equipment if the organic content is above specified quantities. In these cases, the liquid/solid waste has to be sampled, and the total organic content and the possible applicability of the associated air regulations need to be established. Testing of solid/liquid waste for these regulations is included in this DW DQO; however, the criteria for applicability are included in the Data Quality Objectives for Regulatory Requirements for Hazardous and Radioactive Air Emissions Sampling and Analysis (Mulkey 1999). In addition, the regulations in 40 CFR 265, Subpart CC exclude solely mixed waste; therefore, this regulation is only mentioned in Appendix A of this DW DQO. Analysis is not required for solely mixed waste. 


\subsection{FINAL TREATMENT AND DISPOSAL (WAC 173-303)}

The regulations concerning final treatment and disposal in WAC 173-303 include, by reference, the federal regulations of 40 CFR 265 (standards for owners and operators of TSD facilities) and 40 CFR 268 (LDR). Treatment for underlying hazardous constituents under LDR does not fall under the responsibility of RPP and, therefore, is not part of the scope of this DW DQO. 


\subsection{DECISION INPUTS}

This section addresses the selection of analyses needed to meet the demands discussed in Section 3.0. These demands can be separated into needs associated with (1) waste designation, (2) safe handling, interim treatment and storage of the waste, and (3) determining applicability of requirements. Waste designation issues can be addressed by the compounds and characteristics identified in WAC 173-303-090. Analyses required to address issues of waste acceptance into DSTs have been incorporated into the DST WSPS and are incorporated into this document. Issues related to determining applicability of the regulations are the same as those with waste designation but with the addition of analysis for total organics, which is required to address the air emission regulations.

\section{ANALYTE SELECTION PROCESS}

The following sections discuss the regulatory input list and the resulting list of constituents of potential concern (COPCs). Table 4-1 lists the documents that serve as a basis for the COPCs.

Table 4-1. Source of Analytes.

\begin{tabular}{|c|c|c|}
\hline $1 \mathrm{ten} / 4$ & Anulytical Briver & Iremirator of 4 palyte or Citanon Reference \\
\hline 1 & Waste Designation & WAC 173-303-090 \\
\hline 2 & DST WSPS & $\begin{array}{l}\text { Compounds and physical parameters required in WSPS } \\
\text { (non-rad parameters only) }\end{array}$ \\
\hline 3 & $\begin{array}{l}\text { Applicability of } \\
\text { Regulations }\end{array}$ & $\begin{array}{l}40 \text { CFR 265, Subpart BB, CC (if applicable), } 40 \text { CFR } 750 \\
\text { and } 761 \text { (TSCA) }\end{array}$ \\
\hline
\end{tabular}

\section{Double-Shell Tank Waste Stream Profile Sheets}

The DST WSPSs describe the process history and any required analyses of newly generated waste that may be stored in the DST system. Since 1996, a WSPS is required for waste entering the DST system in accordance with the DST Waste Analysis Plan (Mulkey 1998). The DST WSPS have included organics, metals, select radionuclides (total alpha, plutonium-239/240, and uranium-235), and other waste properties such as $\mathrm{pH}$ and specific gravity (hereafter referred to as "physical parameters") (Mulkey 1998). These analyses are not required for DSTs. This DQO, however, does not address analysis for radionuclides, which are not regulated as DW.

\section{Consolidation}

The compounds from the waste designation driver and the DST WSPS were consolidated. Inconsistencies between lists, such as specifying each isomer versus the total compound, were 
resolved. A total of 47 compounds and special parameters were consolidated to create the list of COPCs for this DW DQO, as listed in Table 4-2. The source of the analytes is referenced in Table 4-2; the reference number refers back to Table 4-1.

Table 4-2. Dangerous Waste DQO Constituents of Potential Concern (47 Compounds). (2 Sheets)

\begin{tabular}{|c|c|c|c|}
\hline Cas" & Constitnent & 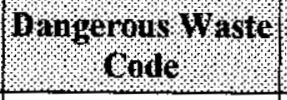 & $\begin{array}{l}\text { Source of inglyte } \\
\text { (Gable }-1,1)\end{array}$ \\
\hline $127-18-4$ & 1,1,2,2-Tetrachloroethene & D039 & 1 \\
\hline 79-01-6 & 1,1,2-Trichloroethylene & D040 & 1 \\
\hline $75-35-4$ & 1,1-Dichloroethene & D029 & 1 \\
\hline $107-06-2$ & 1,2-Dichloroethane & D028 & 1 \\
\hline 75-01-4 & 1-Chloroethene & D043 & 1 \\
\hline 95-95-4 & 2,4,5-Trichlorophenol & D041 & 1 \\
\hline $121-14-2$ & 2,4-Dinitrotoluene & D030 & 1 \\
\hline $78-93-3$ & 2-Butanone (Methyl ethyl ketone) & D035 & 1 \\
\hline $71-43-2$ & Benzene & D018 & 1 \\
\hline $56-23-5$ & Carbon tetrachloride & D019 & 1 \\
\hline $108-90-7$ & Chlorobenzene & D021 & 1 \\
\hline $67-66-3$ & Chloroform & D022 & 1 \\
\hline $1319-77-3$ & Cresols & D026 & 1 \\
\hline $87-68-3$ & Hexachlorobutadiene & D033 & 1 \\
\hline $67-72-1$ & Hexachloroethane & D034 & 1 \\
\hline $98-95-3$ & Nitrobenzene & D036 & 1 \\
\hline $1336-36-3$ & Polychlorinated biphenyls (PCBs) & & 2,3 \\
\hline $110-86-1$ & Pyridine & D038 & 1 \\
\hline $7664-41-7$ & Ammonia & & 2 \\
\hline $7440-38-2$ & Arsenic & D004 & 1 \\
\hline $7440-39-3$ & Barium & D005 & 1 \\
\hline $7440-43-9$ & Cadmium & D006 & 1 \\
\hline $16887-00-6$ & Chloride & & 2 \\
\hline $7440-47-3$ & Chromium & D007 & 1 \\
\hline $14280-30-9$ & Hydroxide & & 2 \\
\hline $7439-89-6$ & Iron & & 2 \\
\hline $7439-92-1$ & Lead & D008 & 1 \\
\hline $7439-96-5$ & Manganese & & 2 \\
\hline $7439-97-6$ & Mercury & D009 & 1 \\
\hline $7440-02-0$ & Nickel & & 2 \\
\hline $7697-37-2$ & Nitrate & & 2 \\
\hline
\end{tabular}


Table 4-2. Dangerous Waste DQO Constituents of Potential Concern (47 Compounds). (2 Sheets)

\begin{tabular}{|c|c|c|c|}
\hline Cas" & Constituent: & Dangerous Waste? & Source of rinalite \\
\hline $14797-65-0$ & Nitrite & & 2 \\
\hline $7782-49-2$ & Selenium & D010 & 1 \\
\hline $7440-22-4$ & Silver & D011 & 1 \\
\hline $7440-23-5$ & Sodium & & 2 \\
\hline $7440-61-1$ & Uranium & & 2 \\
\hline MOIST & $\%$ moisture $\%$ solids & & 2 \\
\hline COLOR & Color & & 2 \\
\hline NA7 & Energetics & & 2 \\
\hline IGNIT & Ignitability (Flash Point) & D002 & 1,2 \\
\hline NA12 & Organics, separable & & 2 \\
\hline $\mathrm{PH}$ & $\mathrm{pH}$ & D001 & 1,2 \\
\hline SPG & Specific gravity (SpG) & & 2 \\
\hline TOC & Total organic carbon (TOC) & & 2,3 \\
\hline TSS & Total suspended solids & & 2 \\
\hline VOA & Total volatile organic compounds & & 3 \\
\hline NAl15 & Viscosity & & 2 \\
\hline
\end{tabular}

CAS\# = chemical abstract services number or unique identifier used in database 
HNF-SD-WM-DQO-025 Rev. 1

This page intentionally left blank. 
HNF-SD-WM-DQO-025 Rev. 1

\subsection{STUDY BOUNDARIES}

The boundary of this document includes all RPP units that generate, store or manage DW. Specifically, this covers the 204 AR Unloading Station, DSTs, SSTs, IMUSTs, DCRT systems, and any identified or new incoming waste stream to the DST system. The boundary also includes all DW generated by the RPP facilities.

RPP neither performs treatment for LDR nor any treatment other than waste stabilization and adjustment for corrosion control parameters; therefore, treatment is not part of this DW DQO. The possible storage of vitrified waste is not within the scope of this DW DQO. 
HNF-SD-WM-DQO-025 Rev. 1

This page intentionally left blank. 


\subsection{DECISION RULES}

Decision rules for needed analyses were formulated by applying the regulatory drivers for generators and interim treatment as discussed in Section 3.0 to the units subject to these requirements. As mentioned in Sections 1.0 and 3.0, this document does not include requirements that are addressed by other documents, such as groundwater monitoring plans and closure plans. This document does not address analyses that will be required for final waste treatment, analyses associated with monitoring for personnel exposure, and analyses associated with transportation issues. As these documents and regulations change, the effects of the changes will need to be evaluated for their effect on analytical requirements.

Table 6-1 provides the action limits for this DW DQO. The action limits are based on the regulatory levels provided in WAC 173-303-090 ("Dangerous Waste Characteristics").

Table 6-1. Action Limit as Specified by Regulatory Drivers. (2 Sheets)

\begin{tabular}{|c|c|c|c|c|}
\hline \multirow[b]{2}{*}{ cas } & \multirow[b]{2}{*}{ Analyte } & \multirow[b]{2}{*}{ WSPS } & \multicolumn{2}{|c|}{ Aetron Limil for Waste Besignation } \\
\hline & & & 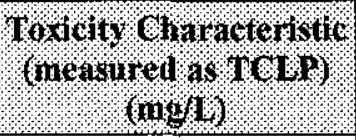 & (10ting) \\
\hline MOIST & $\%$ moisture $/ \%$ solids & $\mathrm{X}$ & & \\
\hline $127-18-4$ & 1,1,2,2-Tetrachloroethene & & 0.7 & 14 \\
\hline $79-01-6$ & 1,1,2-Trichloroethylene & & 0.5 & 10 \\
\hline $75-35-4$ & 1,1-Dichloroethene & & 0.7 & 14 \\
\hline $107-06-2$ & 1,2-Dichloroethane & & 0.5 & 10 \\
\hline $75-01-4$ & 1-Chloroethene & & 0.2 & 4 \\
\hline $95-95-4$ & 2,4,5-Trichlorophenol & & 400 & 8000 \\
\hline $121-14-2$ & 2,4-Dinitrotoluene & & 0.13 & 2.6 \\
\hline $78-93-3$ & 2-Butanone (Methyl ethyl ketone) & & 200 & 4000 \\
\hline $7664-41-7$ & Ammonia & $\mathrm{X}$ & & \\
\hline $7440-38-2$ & Arsenic & & 5 & 100 \\
\hline $7440-39-3$ & Barium & & 100 & 2000 \\
\hline $71-43-2$ & Benzene & & 0.5 & 10 \\
\hline $7440-43-9$ & Cadmium & & 1 & 20 \\
\hline $56-23-5$ & Carbon tetrachloride & & 0.5 & 10 \\
\hline $16887-00-6$ & Chloride & $\mathrm{X}$ & & \\
\hline $108-90-7$ & Chlorobenzene & & 100 & 2000 \\
\hline $67-66-3$ & Chloroform & & 6 & 120 \\
\hline $7440-47-3$ & Chromium & $\mathrm{X}$ & 5 & 100 \\
\hline COLOR & Color & $X$ & & \\
\hline
\end{tabular}


Table 6-1. Action Limit as Specified by Regulatory Drivers. (2 Sheets)

\begin{tabular}{|c|c|c|c|c|}
\hline \multirow[b]{2}{*}{ CAS \# } & \multirow[b]{2}{*}{ Andute } & \multirow[b]{2}{*}{ WSPS } & \multicolumn{2}{|c|}{ Alction Vimi for Waste nesignation. } \\
\hline & & & 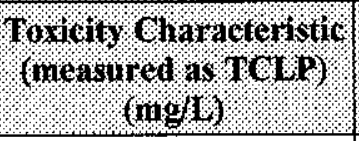 & Totir: \\
\hline $1319-77-3$ & Cresols & & 200 & 4000 \\
\hline NA7 & Energetics & $\mathrm{X}$ & & \\
\hline $87-68-3$ & Hexachlorobutadiene & & 0.5 & 10 \\
\hline $67-72-1$ & Hexachloroethane & & 3 & 60 \\
\hline $14280-30-9$ & Hydroxide & $\mathrm{X}$ & & \\
\hline IGNIT & Ignitability (Flash Point) & $\mathrm{X}$ & & \\
\hline $7439-89-6$ & Iron & $\mathrm{X}$ & & \\
\hline $7439-92-1$ & Lead & & 5 & 100 \\
\hline $7439-96-5$ & Manganese & $\mathrm{X}$ & & \\
\hline $7439-97-6$ & Mercury & & 0.2 & 4 \\
\hline $7440-02-0$ & Nickel & $\mathrm{X}$ & & \\
\hline $7697-37-2$ & Nitrate & $\mathrm{X}$ & & \\
\hline $14797-65-0$ & Nitrite & $\mathrm{X}$ & & \\
\hline $98-95-3$ & Nitrobenzene & & 2 & 40 \\
\hline NA12 & Organics, separable & $\mathrm{X}$ & & \\
\hline PH & $\mathrm{pH}$ & $\mathrm{X}$ & $2.0-12.5 \mathrm{pH}$ units & $2.0-12.5 \mathrm{pH}$ units \\
\hline $1336-36-3$ & Polychlorinated biphenyls (PCBs) & $\mathrm{X}$ & & \\
\hline $110-86-1$ & Pyridine & & 5 & 100 \\
\hline $7782-49-2$ & Selenium & & 1 & 20 \\
\hline $7440-22-4$ & Silver & & 5 & 100 \\
\hline $7440-23-5$ & Sodium & $\mathrm{X}$ & & \\
\hline SPG & Specific gravity (SpG) & $\mathrm{X}$ & & \\
\hline TOC & Total organic carbon (TOC) & $\mathrm{X}$ & 10 weight $\%$ & 10 weight $\%$ \\
\hline TSS & Total suspended solids & $\mathrm{X}$ & & \\
\hline VOA & Total volatile organic compounds & & $500 \mathrm{ppmw}$ & 500 ppmw \\
\hline $7440-61-1$ & Uranium & $\mathrm{X}$ & & \\
\hline NA115 & Viscosity & $\mathrm{x}$ & & \\
\hline
\end{tabular}

*The totals represent the toxicity characteristic limit multiplied by 20 to account for a 20:1 leachate to waste ratio. "If a total analysis of the waste demonstrates that individual analytes are not present in the waste, or that they are present but at such low concentrations that the appropriate regulatory levels could not possibly be exceeded, the TCLP need not be run." (RCRA-309, February 1994.) 
If the action levels as specified in Table 6-1 are exceeded, the following decisions will be made:

- If the highest result of the total organic content analyses exceeds $10 \%$ by weight, the regulations as outlined in 40 CFR 265, Subpart BB apply. See Mulkey (1999) for instructions on handling this type of waste.

- If the $90 \%$ upper confidence limit based on average and one-sided distribution for the total volatile organic analyses exceed $500 \mathrm{ppm}$ by weight, and the waste is NOT a mixed waste, the regulations as outlined in 40 CFR 265, Subpart CC apply. See Mulkey (1999) for instructions on handling this type of waste.

- If the $90 \%$ upper confidence limit based on average and one-sided distribution for all samples exceeds a regulatory action limit, as outlined in 40 CFR 261.24, then the waste is a potential hazardous waste.

- If the nature of the hazardous waste is based on separate matrices, such as supernate and solids, the handling and interim treatment need to be on the separate matrices. Any visible oily liquid layer must be examined separately from the other matrices.

- If the PCB concentration of the waste is $\geq 50 \mathrm{ppm}$, the waste is subject to TSCA regulations. 
HNF-SD-WM-DQO-025 Rev. 1

This page intentionally left blank 


\subsection{DECISION ERROR LIMITS}

The purpose of this step in the DQO process is to assess the consequences of making an incorrect decision as a result of an error, to estimate the allowable error rate, and to use this information to calculate the number of samples (EPA 1994). The parameters listed below are considered in the error assessment and used to calculate the number of samples.

- level of false positives, Type I error with probability alpha,

- level of false negatives, Type II error with probability beta,

- action limits, and

- variance (standard deviation or relative standard deviation).

Normally, the result of the decision error assessment is a recommendation as to the number of samples and the sampling design. Typically, the Type I and II errors, action levels, and variance are known or estimated and the number of samples calculated based on these parameters.

The action limits are first the levels required to assess the waste characteristics of toxicity, corrosivity, and ignitability. The characteristic that has compound specific concentrations is toxicity. These limits are listed in Table 6-1.

In order to evaluate the decision error one must state a hypothesis. The EPA and other statistical guidance recommend that one state a conservative hypothesis (e.g, worst-case). Data generated then support the disproving of the conservative hypothesis.

The hypothesis for those sending waste into the tank farms is that the waste exceeds the action limits. The two decision errors that can be made are:

- Mistakenly concluding that the waste is below the action limit (also called Type I error)

- Mistakenly concluding that the waste is above the action limit (also called power or 1-ß).

Chapter 9 of Test Methods for Evaluating Solid Waste Physical/Chemical Methods (SW-846) (EPA 1997) recommends that one use an upper $90 \%$ confidence limit based on a one-sided distribution. This translates to a Type I error of $10 \%$. The upper $90 \%$ confidence limit based on one-sided distribution is compared to the action limit per SW-846 guidance. SW-846 does not recommend an error rate for mistakenly concluding that the waste is above the action limit. The Multi-Agency Radiation Survey and Site Investigation Manual (MARSSIM) (NRC 1997) which is the latest guidance from the U.S. Nuclear Regulatory Commission, EPA, and the U.S. Department of Energy, does not specify an error rate for mistakenly concluding that the waste is above the action limit. One can evaluate the trade-offs between the cost versus the number of samples required to evaluate the latter decision error. It is recommended but not required that a rate of $20 \%$ be used. This is consistent with the rates being used for waste evaluation by other contractors on the site and consistent with sampling designs being approved by EPA and the Washington State Department of Ecology (Ecology). 
HNF-SD-WM-DQO-025 Rev. 1

This page intentionally left blank. 


\subsection{OPTIMIZATION OF SAMPLING AND ANALYSIS DESIGNS}

The following sections present basic information regarding the design of the sampling and analysis strategy. The information is based on general waste stream knowledge, quality control (QC), and reporting criteria. The analytical requirements specified by this DW DQO can be met by obtaining grab or core samples from each of the DSTs and SSTs. Samples from IMUSTs are needed for DST waste acceptance and can be taken either by grab or core, depending on the waste matrix.

Due to lack of existing analytical results, optimization of sampling requirements cannot be further refined at this time.

\subsection{SAMPLE COLLECTION}

Table 8-1 outlines the waste locations at RPP and frequency of analyses required if sufficient documentation for process knowledge is not available. "Sufficient" means that all the steps leading to the process knowledge used for the decision process are clearly documented.

Samples required by this DQO should be taken from SSTs and IMUSTs prior to the planned shipment of the waste into the DST system. Samples from DSTs should be taken when the waste is staged for shipment for vitrification.

Table 8-1. Analytical Requirements.

\begin{tabular}{|c|c|c|c|c|}
\hline Wiste Shipnent & lasue & Avalyos & frequanct. & THine Constrints \\
\hline SST/DSTs & $\begin{array}{l}\text { Waste designation of } \\
\text { secondary waste and } \\
\text { confirmation of any } \\
\text { existing designation }\end{array}$ & $\begin{array}{l}\text { Analytes listed in } \\
\text { Table 4-2 with a } 1 \text { for } \\
\text { regulatory driver }\end{array}$ & $\begin{array}{l}\text { One time only for each } \\
\text { tank }\end{array}$ & $\begin{array}{l}\text { DSTs: Prior to sending } \\
\text { for disposal } \\
\text { SSTs: Prior to shipment } \\
\text { to DST }\end{array}$ \\
\hline SST/DSTs & $\begin{array}{l}\text { Applicability of } \\
\text { Regulations }\end{array}$ & $\begin{array}{l}\text { Analytes listed in } \\
\text { Table } 4-2 \text { with a } 3 \\
\text { for regulatory driver }\end{array}$ & $\begin{array}{l}\text { Initially one time for } \\
\text { each tank and repeated } \\
\text { if process knowledge } \\
\text { indicates that organic } \\
\text { content may have } \\
\text { changed }\end{array}$ & $\begin{array}{l}\text { DSTs: Prior to sending } \\
\text { for disposal } \\
\text { SSTs: Prior to shipment } \\
\text { to DST }\end{array}$ \\
\hline IMUST/DCRT & $\begin{array}{l}\text { Waste Designation and } \\
\text { Applicability of } \\
\text { Regulations }\end{array}$ & $\begin{array}{l}\text { Analytes listed in } \\
\text { Table 4-2 }\end{array}$ & $\begin{array}{l}\text { One time only for each } \\
\text { tank }\end{array}$ & $\begin{array}{l}\text { Prior to sluicing and } \\
\text { sending the waste to the } \\
\text { DSTs or other facility }\end{array}$ \\
\hline $\begin{array}{l}\text { Newly generated } \\
\text { waste }\end{array}$ & $\begin{array}{l}\text { Waste Designation and } \\
\text { Applicability of } \\
\text { Regulations }\end{array}$ & $\begin{array}{l}\text { Analytes listed in } \\
\text { Table 4-2 }\end{array}$ & $\begin{array}{l}\text { Process knowledge or } \\
\text { one time only analysis } \\
\text { per waste stream }\end{array}$ & $\begin{array}{l}\text { Prior to accepting waste } \\
\text { at RPP }\end{array}$ \\
\hline
\end{tabular}

Note: Analyses for waste designation are optional if sufficient process knowledge is available. The Environmental Compliance and Support Services must concur with any decision not to sample to confirm waste designation. 


\subsubsection{Number of Samples and Type of Collection}

Samples from SSTs, DSTs, and IMUSTs can be obtained by the standard RPP procedures for sample collection. These procedures include sampling by grab sample or by core sampling. The type of sampling depends on the matrix of the tank waste and the expected homogeneity of the waste. In order to obtain appropriate analyte variance multiple samples will be collected as follows:

- For SSTs and DSTs, grab or core samples will be collected from one riser. If activities at the tank allow the use of a second riser, samples will also be obtained from the second riser.

- For IMUSTs and DCRTs with unlimited access to the waste, three vertical profiles will be collected.

- For IMUSTs and DCRTs with limited access, but with two sampling ports or risers, two vertical profile samples will be collected per Table 8-2.

- For IMUSTs and DCRTs with only one riser, one vertical profile sample will be collected by either grab or core depending on whether the waste is liquid or solid.

The required number of samples per vertical location/riser and the collection methods are outlined in Table 8-2. The possible different matrices of a waste are listed in this table.

Depending on the waste location and the matrix or matrices of it, the appropriate sampling technique can be selected. Grab samples shall be taken vertically every $100 \mathrm{~cm}(40 \mathrm{in}$.), at a minimum two grab samples if no other samples are taken of the waste. A core sample shall represent the complete depth of the tank. The sampling location depends on the volume of the waste. If possible, the waste shall be sampled in two different locations to ensure representative samples were taken. For newly generated waste at least three samples from the waste at various depths will be collected or more frequently based on Table $8-2$.

Table 8-2. Sampling Frequency and Location. (2 Sheets)

\begin{tabular}{|c|c|c|c|c|}
\hline Waste loocation & Expected Matrix & Collection Method & Orequency & Sampling rocation \\
\hline \multirow[t]{3}{*}{ SST/DST } & Supernate & Grab & $\begin{array}{l}\text { One sample every } \\
100 \mathrm{~cm}(40 \mathrm{in} .) \\
(\max 3 \text { samples })\end{array}$ & $\begin{array}{l}\text { From } 1 \text { riser, from } \\
\text { second riser if } \\
\text { available }\end{array}$ \\
\hline & Solid & Core & $\begin{array}{l}\text { One sample every } \\
48 \mathrm{~cm}(19 \mathrm{in} .) \\
\text { (assumes } 48 \mathrm{~cm} \\
\text { [19 in.] segments) }\end{array}$ & $\begin{array}{l}\text { From } 1 \text { riser, from } \\
\text { second riser if } \\
\text { available }\end{array}$ \\
\hline & Sludge & Grab or core & Same as above & $\begin{array}{l}\text { From } 1 \text { riser, from } \\
\text { second riser if } \\
\text { available }\end{array}$ \\
\hline
\end{tabular}


Table 8-2. Sampling Frequency and Location. (2 Sheets)

\begin{tabular}{|c|c|c|c|c|}
\hline Waste Location & Expecter Wiatrix & collection Method & Hrequener & sanpling Location \\
\hline \multirow[t]{3}{*}{$\begin{array}{l}\text { IMUST and DCRT, } \\
\text { unrestricted access }\end{array}$} & Supernate & Grab & $\begin{array}{l}\text { One sample every } \\
60 \mathrm{~cm}(2 \mathrm{ft})\end{array}$ & From 3 risers \\
\hline & Solid & Core & $\begin{array}{l}\text { One sample every } \\
48 \mathrm{~cm}(19 \mathrm{in} .) \\
\text { (assumes } 48 \mathrm{~cm} \\
\text { [19 in.] segments) }\end{array}$ & From 3 risers \\
\hline & Sludge & Grab or core & Same as above & From 3 risers \\
\hline \multirow{3}{*}{$\begin{array}{l}\text { IMUST and DCRT, } \\
\text { restricted to one } \\
\text { access point }\end{array}$} & Supernate & Grab & $\begin{array}{l}\text { One sample every } \\
60 \mathrm{~cm}(2 \mathrm{ft})\end{array}$ & From 1 riser/opening \\
\hline & Solid & Core & $\begin{array}{l}\text { One sample every } \\
48 \mathrm{~cm}(19 \mathrm{in} .) \\
\text { (assumes } 48 \mathrm{~cm} \\
\text { [19 in.] segments) }\end{array}$ & From 1 riser/opening \\
\hline & Sludge & Grab or core & Same as above & From 1 riser/opening \\
\hline \multirow{3}{*}{$\begin{array}{l}\text { IMUST and DCRT, } \\
\text { two access locations } \\
\text { (e.g., two risers) }\end{array}$} & Supernate & Grab & $\begin{array}{l}\text { One sample every } \\
60 \mathrm{~cm}(2 \mathrm{ft})\end{array}$ & From 2 risers \\
\hline & Solid & Core & $\begin{array}{l}\text { One sample every } \\
48 \mathrm{~cm} \text { (19 in.) } \\
\text { (assumes } 48 \mathrm{~cm} \\
\text { [19 in.] segments) }\end{array}$ & From 2 risers \\
\hline & Sludge & Grab or core & Same as above & From 2 risers \\
\hline
\end{tabular}

\subsubsection{Field Quality Control}

Quality assurance (QA)/QC samples are used to assess homogeniety, accuracy and precision of both sample collection and analysis. Table 8-3 summarizes the QC sample frequency. Quality control measures taken to support field operations performance include the following:

- Trip Blanks. A trip blank should accompany all samples for volatile analysis. The sample collection bottle shall be filled with organic free water. The filled bottle shall travel with the bottle designated for sample collection. The trip blank bottle(s) shall be labeled in the same manner as the actual samples, but shall have a unique sample number. The trip blank is analyzed for the same volatiles requested for the tank. If no volatile analyses are needed, the trip blank is not required. 
- Equipment Blanks. Equipment blanks will be collected to assess the cleanliness of the sampling equipment, the effectiveness of the sample decontamination process, and potential sampling environment contaminant contribution. Equipment blanks will be collected in the field using analyte free water passed through decontaminated sampling equipment before use of the equipment. Equipment blanks will be collected at a minimum frequency of one per day of sampling. All sample results should be evaluated to determine the possible effects of any contamination that may be detected in the equipment blank. Each analysis will have one equipment blank associated for each waste stream for each week of sampling for each equipment that is reused.

Table 8-3. Field Quality Control Sample Type and Frequency.

\begin{tabular}{|c|c|}
\hline QC Sampie Type & Frequener. \\
\hline Trip Blank & 1 per core or grab sampling event that includes volatile analysis \\
\hline Equipment Blank & $\begin{array}{l}1 \text { per week of sampling for each method to be analyzed of each } \\
\text { waste stream for each equipment used }\end{array}$ \\
\hline
\end{tabular}

\subsection{STORAGE, HOLDTIMES, PRESERVATION OF SAMPLES}

The sample holding time requirements for volatile organic analysis (VOAs), cyanide, mercury, and select anions, as specified in SW-846 (EPA 1997), are difficult to meet for Hanford tank wastes. The logistics of collecting samples from the tanks, arranging transport to the laboratory, and processing the sample casks in the hot cells takes more time than the holding times allowed by the SW-846 methods.

Hanford Site contractors have developed sophisticated equipment and procedures for sampling and analyzing the contents of radioactive waste tanks. The procedures require the following actions, which substantially lengthen the time between sample collection and analysis:

- Collection of samples in specialized core samplers which must be stored and transported in shielded casks,

- Preliminary handling of samples in hot cells using remote manipulators to extrude sample cores from samples and prepare initial subsamples for analysis,

- Storage, handling, and analysis of subsamples in a manner consistent with fissile/TRU material requirements, contamination control, and personnel exposure control. In order to decrease the radioisotope inventory in a given area, many analyses must be processed sequentially, as opposed to simultaneously.

Storage temperature during transport and work in hot cells is difficult to control. Storage of the segments in large sample casks may take place either outside or in rooms in the laboratory. Refrigerators cannot be placed in the hot cells, because of heat overloading on the air handling 
systems for the hot cells. The samples, therefore, cannot be preserved or stored under cold conditions as typically required for volatiles, cyanide for solids and liquids, anions, and mercury on solids until the segment is extruded and waste is subsampled for analysis.

The sample casks shall be maintained within the range of normal temperatures for the time of year when the samples are collected. The ambient temperature outdoors should be noted at the time of collection and daily temperature highs while casks are outside should be noted. The temperature of the hot cell during compositing/extrusion also should be noted.

To summarize, tank samples will be handled with similar care to that used in soil sampling. Losses do occur in core sampling. Care will be taken to ensure that losses in tank waste sample collection are no greater than that typically observed in soil core sampling. Table 8-4 presents the proposed conditions.

No preservations are recommended for supernate for metals. Waste with high salt will precipitate out the metals and the precipitate may not return to solution. Preservation of analytes is performed to retard biological growth and prevent alternation of the chemical species between collection and analysis. DSTs and SSTs are maintained at high $\mathrm{pH}(>8)$. Given the high $\mathrm{pH}$, preservation of the analytes with acids (e.g., for metals) would require extensive addition of acid and would alter the chemical form of the waste. The goal is to assess the waste concentration as it exists; therefore, no preservation will be performed.

\subsection{LAB ANALYSES}

\subsubsection{Laboratory Methods}

The COPCs for this DW DQO are listed in Table 8-5 with the practical quantitation limits (PQLs) the laboratories at Hanford normally obtain. The table also lists the analytical methods as specified in EPA SW-846 (EPA 1997). SW-846 methods shall be the required analytical methods for the analytes.

PCBs in non-liquids must be reported on a dry weight basis. This means that a percent moisture of the sludge or solid must be determined to allow accurate reporting. The phases in liquid samples must be separated and the concentration in each phase reported per Section 3.1. All PCB analysis must be in accordance with SW-846 Method 8082 (EPA 1997) using gas chromatography.

In cases where the action limit is below the PQL, the laboratory shall make a reasonable effort to achieve a PQL below the action limit. It should be noted that the PQL may not be achieved due to matrix effects and radioactivity that is higher than planned. If this is the case, the laboratory report shall explain this situation. 
HNF-SD-WM-DQO-025 Rev. 1

Table 8-4. Storage and Preservation Listed in SW-846 Versus the Actual Conditions Proposed.

\begin{tabular}{|c|c|c|c|c|c|c|}
\hline \multirow[b]{2}{*}{ Metrod } & \multicolumn{3}{|c|}{ SW 846 Methods. } & \multicolumn{3}{|c|}{ Proposert Conditions } \\
\hline & Container & conorition & Preservition & Container & $\begin{array}{l}\text { Storager. } \\
\text { condition. }\end{array}$ & Preservation \\
\hline $\begin{array}{l}\text { Volatiles, } \\
\text { solid }\end{array}$ & $\begin{array}{l}\text { Glass vial } \\
\text { with septa }\end{array}$ & Cool 4 degrees C & $\begin{array}{l}\text { Matrix modifier } \\
\text { or organic free } \\
\text { water }\end{array}$ & $\begin{array}{l}\text { Glass vial } \\
\text { with septa }\end{array}$ & Cool 4 degrees C & $\begin{array}{l}\text { Matrix modifier } \\
\text { will be added in } \\
\text { the hot cell to the } \\
\text { subsample per } \\
\text { the method. }\end{array}$ \\
\hline $\begin{array}{l}\text { Volatiles, } \\
\text { liquid, no } \\
\text { residual } \\
\text { chlorine } \\
\text { present }\end{array}$ & $\begin{array}{l}\text { Glass vial } \\
\text { with septa }\end{array}$ & Cool 4 degrees $\mathrm{C}$ & $\begin{array}{l}\text { Adjust } \mathrm{pH}<2 \\
\text { with sulfuric acid, } \\
\text { or } \mathrm{HCl} \text {, or solid } \\
\mathrm{NaHSO} 4\end{array}$ & $\begin{array}{l}\text { Glass vial } \\
\text { with septa }\end{array}$ & Cool 4 degrees $\mathrm{C}$ & None \\
\hline $\begin{array}{l}\text { Cyanide } \\
\text { (supernate) }\end{array}$ & $\begin{array}{l}\text { Plastic/ } \\
\text { glass }\end{array}$ & Cool 4 degrees $\mathrm{C}$ & $\begin{array}{l}\text { Adjust } \mathrm{pH}>12 \\
\text { with } \mathrm{NaOH} \text {, check } \\
\text { for oxidizers and } \\
\text { add ascorbic acid }\end{array}$ & Plastic & $\begin{array}{l}\text { Ambient in hot } \\
\text { cell }\end{array}$ & $\begin{array}{l}\text { Measure } \mathrm{pH} \\
\text { supernate with } \\
\text { pH paper. If the } \\
\text { pH } \geq 7 \text {, adjust } \\
\text { pH }>12 \text { with } \\
\mathrm{NaOH} \text {. If } \mathrm{pH}<7 \text {, } \\
\text { no } \mathrm{NaOH} \text { should } \\
\text { be added. }\end{array}$ \\
\hline $\begin{array}{l}\text { Cyanide } \\
\text { (solid) }\end{array}$ & Plastic/glass & Cool 4 degrees $\mathrm{C}$ & None & Plastic & $\begin{array}{l}\text { Ambient in hot } \\
\text { cell }\end{array}$ & None \\
\hline $\begin{array}{l}\text { Anions } \\
\text { (supernate) }\end{array}$ & Plastic & Cool 4 degrees $\mathrm{C}$ & None & Plastic & $\begin{array}{l}\text { Ambient in hot } \\
\text { cell }\end{array}$ & None \\
\hline $\begin{array}{l}\text { Mercury } \\
\text { and Metals } \\
\text { (solid) }\end{array}$ & Plastic & $\begin{array}{l}\text { Cool } 4 \text { degrees } C \\
(+/-2 \text { degrees for } \\
\text { solid })\end{array}$ & None & Plastic & $\begin{array}{l}\text { Ambient in hot } \\
\text { cell }\end{array}$ & None \\
\hline $\begin{array}{l}\text { Mercury } \\
\text { and Metals } \\
\text { (liquid) }\end{array}$ & Plastic & None & $\mathrm{HNO}_{3}$ to $\mathrm{pH}<2$ & Plastic & $\begin{array}{l}\text { Ambient in hot } \\
\text { cell }\end{array}$ & None \\
\hline
\end{tabular}


Table 8-5. Dangerous Waste COPC Analytical Requirements. (2 Sheets)

\begin{tabular}{|c|c|c|c|c|}
\hline Q AS: & Constitivent & SWetitor & 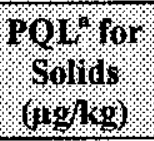 & 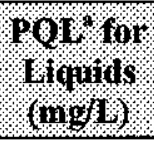 \\
\hline $127-18-4$ & 1,1,2,2-Tetrachloroethene & $8260 \mathrm{~B}$ & 28 & 0.56 \\
\hline $79 \curvearrowleft 01-6$ & 1,1,2-Trichloroethylene & $8260 \mathrm{~B}$ & 20 & 0.4 \\
\hline $75-35-4$ & 1,1-Dichloroethene & $8260 \mathrm{~B}$ & 28 & 0.56 \\
\hline $107-06-2$ & 1,2-Dichloroethane & $8260 \mathrm{~B}$ & 20 & 0.4 \\
\hline $75 \backsim 01-4$ & 1-Chloroethene & $8260 \mathrm{~B}$ & 8 & 0.16 \\
\hline $95-95-4$ & 2,4,5-Trichlorophenol & $8270 \mathrm{C}$ & 16,000 & 320 \\
\hline $121-14-2$ & 2,4-Dinitrotoluene & $8270 \mathrm{C}$ & 5.2 & 0.104 \\
\hline 78-93-3 & 2-Butanone (Methyl ethyl ketone) & $8260 \mathrm{~B}$ & 8,000 & 160 \\
\hline $71-43-2$ & Benzene & $8260 \mathrm{~B}$ & 20 & 0.4 \\
\hline $56-23-5$ & Carbon tetrachloride & $8260 \mathrm{~B}$ & 20 & 0.4 \\
\hline $108-90-7$ & Chlorobenzene & $8260 \mathrm{~B}$ & 4,000 & 80 \\
\hline $67-66-3$ & Chloroform & $8260 \mathrm{~B}$ & 240 & 4.8 \\
\hline $1319-77-3$ & Cresols & $8270 \mathrm{C}$ & 8,000 & 160 \\
\hline $87-68-3$ & Hexachlorobutadiene & $8260 \mathrm{~B}$ & 20 & 0.4 \\
\hline 67-72-1 & Hexachloroethane & $8260 \mathrm{~B}$ & 120 & 2.4 \\
\hline $98-95-3$ & Nitrobenzene & $8260 \mathrm{~B}$ & 80 & 1.6 \\
\hline $1336-36-3$ & Polychlorinated biphenyls (PCBs) & 8082 & 1.6 & 1.6 \\
\hline $110-86-1$ & Pyridine & $8270 \mathrm{C}$ & 200 & 4.0 \\
\hline $7664-41-7$ & Ammonia & 9056/ISE & $\mathrm{c}$ & 8 \\
\hline $7440-38-2$ & Arsenic & $6010 \mathrm{~B}$ & 200 & 4.0 \\
\hline $7440-39-3$ & Barium & $6010 \mathrm{~B}$ & 4,000 & 80 \\
\hline $7440-43-9$ & Cadmium & $6010 \mathrm{~B}$ & 40 & 0.8 \\
\hline $7440-47-3$ & Chromium & $6010 \mathrm{~B}$ & 200 & 4.0 \\
\hline $14280-30-9$ & Hydroxide & 310.1 & c & c \\
\hline $7439-89-6$ & Iron & $6010 \mathrm{~B}$ & c & " \\
\hline $7439-92-1$ & Lead & $6010 \mathrm{~B}$ & 200 & 4.0 \\
\hline $7439-96-5$ & Manganese & $6010 \mathrm{~B}$ & ${ }^{\circ}$ & c \\
\hline $7439-97-6$ & Mercury & $7470 / 7471$ & 8 & 0.16 \\
\hline $7440-02-0$ & Nickel & $6010 \mathrm{~B}$ & c & c \\
\hline $7697-37-2$ & Nitrate & 9056 & c & c \\
\hline $14797-65-0$ & Nitrite & 9056 & c & ${ }^{\circ}$ \\
\hline $16887-00-6$ & Chloride & 9056 & c & c \\
\hline $7782-49-2$ & Selenium & 9056 & 4 & 0.8 \\
\hline $7440-22-4$ & Silver & $6010 \mathrm{~B}$ & 200 & 4.0 \\
\hline
\end{tabular}


Table 8-5. Dangerous Waste COPC Analytical Requirements. (2 Sheets)

\begin{tabular}{|c|c|c|c|c|}
\hline $\mathrm{CASH}$ & Constifient & SW & $(4 \mathrm{~g} / \mathrm{sg})$ & $(\mathrm{cos})$ \\
\hline $7440-23-5$ & Sodium & $6010 \mathrm{~B}$ & c & c \\
\hline $7440-61-1$ & Uranium & 6020 & c & c \\
\hline MOIST & $\%$ moisture $/ \%$ solids & gravimetric & $c$ & ${ }^{\circ}$ \\
\hline COLOR & Color & 110.1 & c & ${ }^{\circ}$ \\
\hline NA7 & Energetics & DSC & c & c \\
\hline IGNIT & Ignitability (Flash Point) $^{b}$ & $1010 / 1030$ & $70-140^{\circ} \mathrm{F}$ & $70-140^{\circ} \mathrm{F}$ \\
\hline NA12 & Organics, separable & & c & c \\
\hline $\mathrm{PH}$ & $\mathrm{pH}$ & $9040 / 9045$ & ${ }^{\circ}$ & c \\
\hline SPG & Specific gravity (SpG) & & c & c \\
\hline TOC & Total organic carbon (TOC) & 9060 & 8,000 & 80 \\
\hline TSS & Total suspended solids & 160.1 & c & c \\
\hline VOA & Total volatile organic compounds & $8260 \mathrm{~B}$ & 8,000 & 80 \\
\hline NAl15 & Viscosity & & c & c \\
\hline
\end{tabular}

${ }^{a} \mathrm{PQL}$ may be higher than specified due to the concentration of radionuclides in the waste matrix. PQLs were calculated $20 \%$ lower than the regulatory action limits.

${ }^{\mathrm{b}}$ Ignitability will not be performed if the radionuclide content of the sample posses a safety danger to personnel.

'Analyze for; no specific detection limits required.

DSC $=$ Differential Screening Calorimetry (not an SW-846 Method)

ISE $=$ ion-selective electrode

\subsubsection{Lab Quality Control}

Control measures taken to monitor laboratory performance include the following:

- One laboratory method blank for every 20 samples of similar matrix ( $5 \%$ of samples) or preparation batch, will be carried through the complete sample preparation and analytical procedure. The method blank consists of analyte-free water and will be used to document contamination resulting from the analytical process.

- One laboratory control sample (LCS) or blank spike will be performed for every preparation batch of up to 20 samples of same matrix for each analytical method to monitor the effectiveness of the sample preparation and analysis process. The results from the analyses are used to assess laboratory performance.

- A matrix spike (MS) sample will be prepared and analyzed for every 20 samples (as applicable to method) of the same matrix or sample preparation batch, whichever is most frequent. An aliquot of the sample is spiked with the analytes of concern and the results of the MSs are used to document the bias of an analytical process in a given matrix. 
- Laboratory duplicates or matrix spike duplicates (MSDs) will be used to assess precision and will be analyzed at the same frequency as the MSs. A laboratory duplicate is an aliquot of the same sample, while a MSD is a second MS of the same sample. To compare two values, the relative percent difference (RPD) is based on the mean of the two values, and is reported as an absolute value. Either a lab duplicate or MSD will be performed for every preparation batch of up to 20 samples of same matrix for each analytical method.

- For metals such as sodium and aluminum, a serial dilution may be performed to assess the accuracy of the analyte measurement. A serial dilution is required for analytes with concentrations that approach the upper limit of the linear range. The serial dilution should be performed on the same sample as the MS analysis. This will enable the assessment of the accuracy of the analysis when spike concentration is insufficient for the analysis due to the high analyte concentration in the sample. The results for the serial dilution must be reported in addition to the MS recovery when the spike recovery falls outside of the acceptance range.

Table 8-6 lists the analytical methods and the required QC limits. Table 8-7 provides the frequency of these QC samples.

Table 8-6. Analytes for Quality Control Criteria.

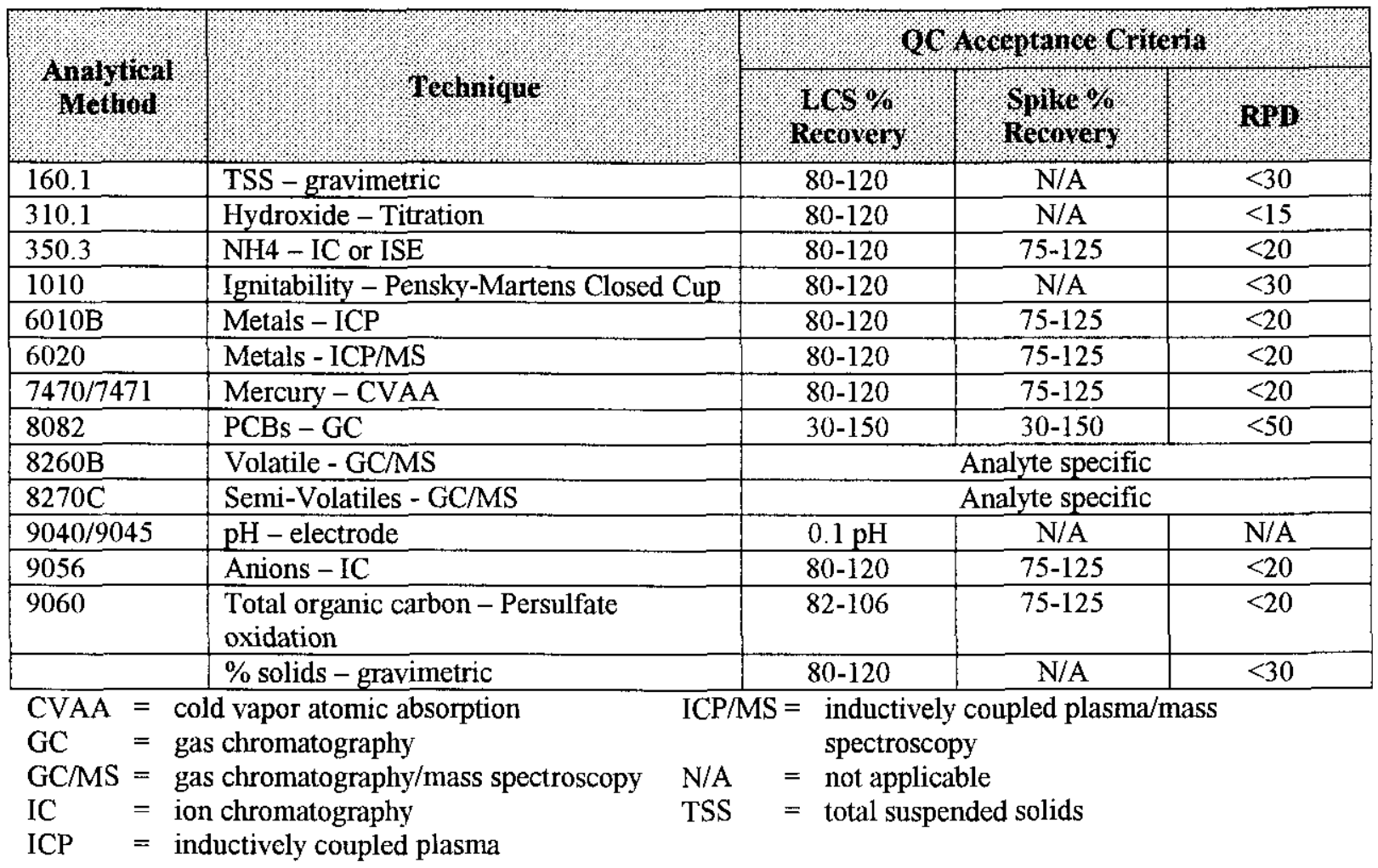


Table 8-7. Lab Quality Control Sample Type and Frequency.

\begin{tabular}{|c|c|}
\hline OCSample TYpe & Frequenus: \\
\hline Laboratory Method Blank \& LCS & \multirow[t]{3}{*}{1 per 20 samples of same matrix, same preparation batch } \\
\hline MS & \\
\hline Laboratory Duplicate or MSD & \\
\hline
\end{tabular}

\subsection{DATA REDUCTION AND REPORTING}

While it is imperative that all data be produced following approved procedures, it should be recognized that the tank wastes are unique materials and some modifications to standard operating procedures may be required to generate technically valid analytical data. If such modifications are necessary, they must be clearly documented following the required protocols.

To the extent technically reasonable, "spike recovery" analyses will be performed to assess accuracy of the analytical method.

The data report shall show the precision (RPD) and accuracy (spike recovery) of the data. All analytes requiring reruns are to be explained in the case narrative. All raw data supporting such reruns shall be archived and available for review.

All analytical and supporting QA/QC results will undergo a one over one technical review prior to the data report being issued. An independent data validation (an administrative review of laboratory documents conducted for supporting regulatory compliance requirements) is not required for data developed under this DQO. Spatial and statistical evaluation of the analytical data will be performed. 
HNF-SD-WM-DQO-025 Rev. 1

\subsection{REFERENCES}

40 CFR 260, et seq., 1998, "Hazardous Waste Management System," Code of Federal Regulations, as amended.

40 CFR 372, 1998, "Toxic Chemical Release Reporting: Community Right-to-Know," Code of Federal Regulations, as amended.

40 CFR 750 and 761, 1998, "Disposal of Polychlorinated Biphenyls (PCBs); Final Rule, Code of Federal Regulations, as amended.

Atomic Energy Act of 1954, 42 U.S.C. 2011, et seq.

Banning, D. L., 1996, Data Quality Objectives Procedure, WHC-IP-1216, Rev. 1, Westinghouse Hanford Company, Richland, Washington.

Comprehensive Environmental Response, Compensation, and Liability Act of 1980 , 42 U.S.C. 9601 , et seq.

EPA, 1994, Guidance for the Data Quality Objectives Process, EPA QA/G-4, U.S. Environmental Protection Agency, Washington, D.C.

EPA, 1997, Test Methods for Evaluating Solid, Waste Physical/Chemical Methods, SW-846, $3^{\text {rd }}$ Edition, as amended by Updates I (July 1992) IIA (August 1993), IIB (January 1995), and III (1997), U.S. Environmental Protection Agency, Washington, D.C.

Mulkey, C. H., 1996, Single-Shell Tank System Waste Analysis Plan, WHC-EP-0356, Rev. 1, Westinghouse Hanford Company, Richland, Washington.

Mulkey, C. H., 1998, Double-Shell Tank Waste Analysis Plan, WHC-SD-WM-EV-053, Rev. 5, Westinghouse Hanford Company, Richland, Washington.

Mulkey, C. H., 1999, Data Quality Objectives for Regulatory Requirements for Hazardous and Radioactive Air Emissions Sampling and Analysis, WHC-SD-WM-DQO-021, Rev. 1, Westinghouse Hanford Company, Richland, Washington.

NRC, 1997, Multi-Agency Radiation Survey and Site Investigation Manual (MARSSIM), NUREG-1575, U.S. Nuclear Regulatory Commission, Washington, D.C.

Nuclear Waste Policy Act of 1982, Public Law 97-425, Jan. 7, 1983, 42 U.S.C. 10101, et seq.

PHMC, 1998, Hanford Site Solid Waste Acceptance Criteria, HNF-EP-0063, Rev. 5, Project Hanford Management Contractor, Richland, Washington. 
HNF-SD-WM-DQO-025 Rev. 1

Resource Conservation and Recovery Act of 1976, 42 U.S.C. 6901, et seq.

WAC 173-303, "Dangerous Waste Regulations," Washington Administrative Code, as amended. 
HNF-SD-WM-DQO-025 Rev. 1

APPENDIX A

REGULATIONS THAT MAY REQUIRE ANALYSES

A-i 
HNF-SD-WM-DQO-025 Rev. 1

This page intentionally left blank. 
Table A-1. Regulations That May Require Analyses. (5 Sheets)

\begin{tabular}{|c|c|c|c|c|}
\hline Item \# & 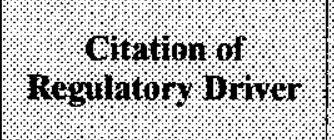 & Potential inniptical & 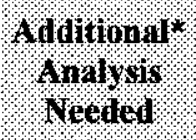 & Ritionale \\
\hline 11 & $\begin{array}{l}\text { WAC } 173-303-300 \\
(2-5)\end{array}$ & $\begin{array}{c}\text { Confirmation of } \\
\text { designation of waste } \\
\text { received by the River } \\
\text { Protection Project } \\
\text { (RPP) }\end{array}$ & No & $\begin{array}{l}\text { Waste received by the RPP is limited to waste } \\
\text { sent to the double-shell tank (DST) system. } \\
\text { The DST Waste Analysis Plan (Mulkey 1998) } \\
\text { sets forth confirmation requirements and } \\
\text { adherence to its requirements should be } \\
\text { sufficient to ensure safe storage of the waste. } \\
\text { Because waste is not segregated by waste } \\
\text { codes in the DSTs, confirmation of specific } \\
\text { waste stream designation would add little } \\
\text { value. }\end{array}$ \\
\hline 12 & $\begin{array}{l}\text { WAC 173-303-390 } \\
(2),(3)\end{array}$ & Facility Reporting & No & $\begin{array}{l}\text { Release reports and groundwater monitoring } \\
\text { are routinely submitted to the appropriate } \\
\text { parties. Existing programs and data quality } \\
\text { objectives (DQOs) should obtain the necessary } \\
\text { information, therefore additional analyses are } \\
\text { necessary at this time. }\end{array}$ \\
\hline 13 & WAC $173-303-395(1)$ & $\begin{array}{l}\text { Precautions for } \\
\text { ignitable, reactive, or } \\
\text { incompatible waste. }\end{array}$ & No & $\begin{array}{l}\text { The waste in the tanks does not exhibit the } \\
\text { characteristics of ignitability or reactivity. } \\
\text { Requirements in the compatibility DQO } \\
\text { (Mulkey et al. 1999) take into consideration the } \\
\text { potential for propagating chemical reactions } \\
\text { and the mixing of incompatible waste. } \\
\text { Therefore no additional analyses are necessary } \\
\text { at this time. }\end{array}$ \\
\hline 14 & WAC $173-303-395(2)$ & $\begin{array}{l}\text { Other environmental } \\
\text { laws and regulations }\end{array}$ & No & $\begin{array}{l}\text { As long as the requirements specified in the } \\
\text { wastewater and air regulatory DQOs are } \\
\text { followed, no additional analyses are needed to } \\
\text { address other environmental laws and } \\
\text { regulations. }\end{array}$ \\
\hline 15 & $\begin{array}{l}\text { WAC 173-303-395 } \\
\text { (3) }\end{array}$ & Asbestos & No & $\begin{array}{l}\text { Adherence to Hanford Site procedures for } \\
\text { asbestos is sufficient and no additional analyses } \\
\text { are needed. }\end{array}$ \\
\hline 16 & WAC $173-303-395(5)$ & $\begin{array}{l}\text { Storage time limits for } \\
\text { surface impoundments } \\
\text { and piles. }\end{array}$ & No & $\begin{array}{l}\text { Contaminated equipment stored by RPP could } \\
\text { be considered waste piles. RPP contaminated } \\
\text { equipment is being managed in accordance } \\
\text { with site wide policy which has been reviewed } \\
\text { and agreed to by the Washington State } \\
\text { Department of Ecology (Ecology). Therefore, } \\
\text { no additional analysis of this equipment is } \\
\text { being required at this time. No surface } \\
\text { impoundments are in the boundary of this } \\
\text { document. }\end{array}$ \\
\hline 17 & WAC 173-303-395(6) & $\begin{array}{c}\text { Container and tank } \\
\text { labeling requirements }\end{array}$ & No & $\begin{array}{l}\text { Existing process knowledge is sufficient to } \\
\text { address labeling requirements. }\end{array}$ \\
\hline
\end{tabular}


HNF-SD-WM-DQO-025 Rev. 1

Table A-1. Regulations That May Require Analyses. (5 Sheets)

\begin{tabular}{|c|c|c|c|c|}
\hline Itena II & Regulation oritrer. & 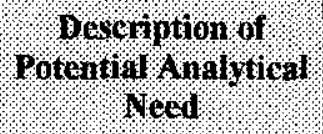 & $\begin{array}{l}\text { Adinionat? } \\
\text { Analysis: }\end{array}$ & Raturule \\
\hline 18 & $\begin{array}{l}\text { WAC 173-303-400 } \\
(2)(\mathrm{b})(\mathrm{ix})\end{array}$ & $\begin{array}{c}\text { Elementary } \\
\text { neutralization pits }\end{array}$ & No & $\begin{array}{l}\text { RPP does not have equipment that meets the } \\
\text { definition of elementary neutralization pits. }\end{array}$ \\
\hline 19 & $\begin{array}{l}\text { WAC } 173-303-400 \\
\text { (3)(a) }\end{array}$ & $\begin{array}{l}\text { Requirements in } 40 \\
\text { CFR 265, Subparts F } \\
\text { to R, Subpart W, } \\
\text { Subparts AA, BB, } \\
\text { CC, and DD }\end{array}$ & $\begin{array}{l}\text { See separate } \\
\text { responses for } \\
\text { each of these } \\
\text { sections in } \\
\text { Table 3-1 and } \\
\text { this Appendix }\end{array}$ & $\begin{array}{l}\text { The state requirements incorporate the federal } \\
\text { requirements by reference. }\end{array}$ \\
\hline 20 & WAC 173-303-505 & $\begin{array}{l}\text { Recyclable material } \\
\text { used in a manner } \\
\text { constituting disposal }\end{array}$ & No & $\begin{array}{l}\text { RPP does not handle any of its dangerous } \\
\text { waste (DW) in this manner, therefore no } \\
\text { analysis is necessary. }\end{array}$ \\
\hline 21 & $\begin{array}{l}\text { WAC 173-303-506 } \\
\text { (2)(a)(ii) \& (iii) }\end{array}$ & $\begin{array}{l}\text { Reclamation of } \\
\text { chlorofluorocarbons } \\
\& \text { chlorinated } \\
\text { fluorocarbons }\end{array}$ & No & $\begin{array}{l}\text { Existing programs handle the inspection and } \\
\text { repair of equipment containing } \\
\text { chlorofluorocarbons and chlorinated } \\
\text { fluorocarbons so no analysis is needed by RPP } \\
\text { to address these issues. }\end{array}$ \\
\hline 22 & $\begin{array}{l}\text { WAC 173-303-510, } \\
515\end{array}$ & $\begin{array}{l}\text { Use of used oil or DW } \\
\text { for fuel }\end{array}$ & No & $\begin{array}{l}\text { RPP does not reuse any of its used oil or waste } \\
\text { for fuel so no analyses are necessary. }\end{array}$ \\
\hline 23 & WAC $173-303-610$ & $\begin{array}{l}\text { Closure and } \\
\text { postclosure }\end{array}$ & No & $\begin{array}{l}\text { Closure of RPP will be specifically addressed } \\
\text { in closure plans. Therefore this document will } \\
\text { not further address these issues. }\end{array}$ \\
\hline 24 & $\begin{array}{l}\text { WAC } 173-303-630 \\
(3),(4)\end{array}$ & $\begin{array}{l}\text { Labeling and } \\
\text { compatibility of waste } \\
\text { with storage } \\
\text { containers }\end{array}$ & No & $\begin{array}{l}\text { Existing process knowledge is generally } \\
\text { sufficient to satisfy labeling requirements. }\end{array}$ \\
\hline 25 & WAC $173-303-630(9)$ & $\begin{array}{l}\text { Special requirements } \\
\text { for incompatible } \\
\text { wastes }\end{array}$ & No & $\begin{array}{l}\text { RPP waste typically placed in drums consists } \\
\text { of contaminated equipment, clothing and other } \\
\text { miscellaneous items. Due to the nature of this } \\
\text { type of waste it is unlikely that any of the waste } \\
\text { will be incompatible with the container. There } \\
\text { can be an exception to this, but the exceptions } \\
\text { should be dealt with on an individual basis and } \\
\text { not specifically in this document. }\end{array}$ \\
\hline 26 & WAC $173-303-640(3)$ & $\begin{array}{l}\text { Design and } \\
\text { installation of new } \\
\text { tank systems }\end{array}$ & No & $\begin{array}{l}\text { This section requires that a registered corrosion } \\
\text { engineer address specific soil conditions } \\
\text { relating to corrosion during the design and } \\
\text { installation of a new tank system. Depending } \\
\text { on the availability of existing information, the } \\
\text { corrosion engineer may need analysis of the } \\
\text { soil. This determination must be made on an } \\
\text { individual basis so is not included in this } \\
\text { document. }\end{array}$ \\
\hline
\end{tabular}


Table A-1. Regulations That May Require Analyses. (5 Sheets)

\begin{tabular}{|c|c|c|c|c|}
\hline ltem \# & Regulatory oriver. & rotential Rinifitical & $\begin{array}{l}\text { Additivnal' } \\
\text { Analysis: } \\
\text { Meeded }\end{array}$ & Rationale \\
\hline 27 & $\begin{array}{l}\text { WAC 173-303-640 } \\
\text { (5)(d),(e) }\end{array}$ & $\begin{array}{c}\text { General requirements } \\
\text { pertaining to design } \\
\text { and labeling of tank } \\
\text { systems }\end{array}$ & No & $\begin{array}{l}\text { Existing knowledge is adequate to address } \\
\text { design and labeling issues. }\end{array}$ \\
\hline 28 & $\begin{array}{l}\text { WAC } 173-303-645 \\
(4),(5)\end{array}$ & $\begin{array}{l}\text { Groundwater } \\
\text { monitoring for } \\
\text { releases from tanks }\end{array}$ & No & $\begin{array}{l}\text { These sections require Ecology to specify in } \\
\text { the facility permit the DW constituents that } \\
\text { must be monitored. At this time, RPP is under } \\
\text { Interim Status and the facility permit has not } \\
\text { yet been issued. Once the permit is issued it } \\
\text { should specify any required analyses. }\end{array}$ \\
\hline 29 & $\begin{array}{l}\text { WAC } 173-303-646 \\
(5)\end{array}$ & $\begin{array}{l}\text { Monitoring of } \\
\text { corrective action } \\
\text { management unit } \\
\quad \text { (CAMU) }\end{array}$ & No & $\begin{array}{l}\text { Ecology must specify monitoring requirements } \\
\text { for CAMUs. At this time RPP does not have } \\
\text { any CAMUs, therefore this requirement is not } \\
\text { applicable. }\end{array}$ \\
\hline 30 & $\begin{array}{l}\text { WAC 173-303-650 } \\
\text { (11)(c) }\end{array}$ & $\begin{array}{l}\text { Response action to } \\
\text { surface impoundment } \\
\text { leaks }\end{array}$ & No & $\begin{array}{l}\text { No surface impoundments are in the boundary } \\
\text { of this document. }\end{array}$ \\
\hline 31 & $\begin{array}{l}\text { WAC } 173-303-660 \\
\text { (7) }\end{array}$ & $\begin{array}{c}\text { Special requirements } \\
\text { for ignitable and } \\
\text { reactive waste placed } \\
\text { in piles }\end{array}$ & No & $\begin{array}{l}\text { RPP waste piles consist of contaminated } \\
\text { equipment that does not exhibit the } \\
\text { characteristics of ignitability and reactivity. } \\
\text { (See \#13.) }\end{array}$ \\
\hline 32 & $\begin{array}{l}\text { WAC } 173-303-660 \\
(8)\end{array}$ & $\begin{array}{l}\text { Special requirements } \\
\text { for incompatible } \\
\text { waste placed in piles }\end{array}$ & No & $\begin{array}{l}\text { RPP waste piles consist of contaminated } \\
\text { equipment and there should not be any } \\
\text { compatibility problems associated with the } \\
\text { equipment. }\end{array}$ \\
\hline 33 & WAC $173-303-690$ & $\begin{array}{l}\text { Air emissions from } \\
\text { process vents }\end{array}$ & No & $\begin{array}{l}\text { No RPP facility falls within the purview of this } \\
\text { regulation. }\end{array}$ \\
\hline 34 & $\begin{array}{l}40 \text { CFR } 264,265 \\
\text { Subpart F }\end{array}$ & $\begin{array}{l}\text { Groundwater } \\
\text { Monitoring }\end{array}$ & No & $\begin{array}{l}\text { Groundwater monitoring is being addressed by } \\
\text { a separate group. There are no known } \\
\text { deficiencies which need to be addressed by this } \\
\text { document. }\end{array}$ \\
\hline 35 & $\begin{array}{l}40 \text { CFR 264, } 265 \\
\text { Subpart G }\end{array}$ & $\begin{array}{l}\text { Closure and Post } \\
\text { Closure }\end{array}$ & No & $\begin{array}{l}\text { Analytical requirements for closure and post } \\
\text { closure will be documented in plans approved } \\
\text { by the regulators. }\end{array}$ \\
\hline 36 & $\begin{array}{l}40 \text { CFR 264, } 265 \\
\text { Subpart H }\end{array}$ & $\begin{array}{c}\text { Financial } \\
\text { Requirements }\end{array}$ & No & $\begin{array}{l}\text { Any analytical needs will be addressed in the } \\
\text { closure plans under item \#35. }\end{array}$ \\
\hline 37 & $\begin{array}{l}40 \text { CFR 264, } 265 \\
\text { Subpart I }\end{array}$ & $\begin{array}{l}\text { Container } \\
\text { management }\end{array}$ & No & These issues are addressed in items $\# 24$ and 25 \\
\hline 38 & $\begin{array}{l}40 \text { CFR 264, } 265 \\
\text { Subparts J }\end{array}$ & Tank Systems & No & $\begin{array}{l}\text { These issues are addressed in items \#13, } 17 \text {, } \\
25,26,27 \text {, and } 28 \text {. }\end{array}$ \\
\hline
\end{tabular}


HNF-SD-WM-DQO-025 Rev. 1

Table A-1. Regulations That May Require Analyses. (5 Sheets)

\begin{tabular}{|c|c|c|c|c|}
\hline ltera \# & 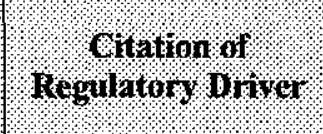 & 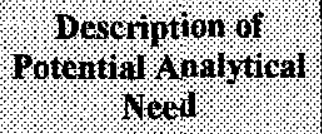 & Adaitional" & rationalo \\
\hline 39 & $\begin{array}{l}40 \text { CFR 264, } 265 \\
\text { Subpart K }\end{array}$ & $\begin{array}{c}\text { Surface } \\
\text { Impoundments }\end{array}$ & No & $\begin{array}{l}\text { No surface impoundments are in the boundary } \\
\text { of this document. }\end{array}$ \\
\hline 40 & $\begin{array}{l}40 \text { CFR 264, } 265 \\
\text { Subpart L }\end{array}$ & Waste Piles & No & These issues are addressed in items $\# 31$ and 32 \\
\hline 41 & $\begin{array}{l}40 \text { CFR 264, } 265 \\
\text { Subpart M }\end{array}$ & Land Treatment & No & $\begin{array}{l}\text { RPP does not operate any land treatment } \\
\text { facilities. }\end{array}$ \\
\hline 42 & $\begin{array}{l}40 \text { CFR 264, } 265 \\
\text { Subpart N }\end{array}$ & Landfills & No & RPP does not operate any landfills. \\
\hline 43 & $\begin{array}{l}40 \text { CFR 264, } 265 \\
\text { Subpart O }\end{array}$ & Incinerator & No & RPP does not operate any incinerators. \\
\hline 44 & $\begin{array}{l}40 \text { CFR 264, } 265 \\
\text { Subpart P }\end{array}$ & Thermal Treatment & No & $\begin{array}{l}\text { Any analytical requirements must be met by } \\
\text { the vitrification contractor. }\end{array}$ \\
\hline 45 & $\begin{array}{l}40 \text { CFR 264, } 265 \\
\text { Subpart Q }\end{array}$ & $\begin{array}{l}\text { Chemical, physical, } \\
\text { and biological } \\
\text { treatment }\end{array}$ & No & $\begin{array}{l}\text { These issues can be very case specific and are } \\
\text { not being addressed at this time. }\end{array}$ \\
\hline 46 & $\begin{array}{l}\text { 40 CFR 264, } 265 \\
\text { Subpart R }\end{array}$ & $\begin{array}{l}\text { Underground } \\
\text { Injection }\end{array}$ & No & $\begin{array}{l}\text { RPP does not operate any disposal unit where } \\
\text { DW is sent to underground injection wells. }\end{array}$ \\
\hline 47 & $\begin{array}{l}40 \text { CFR 264, } 265 \\
\text { Subpart W }\end{array}$ & Drip Pads & No & $\begin{array}{l}\text { No analyses are needed to address these } \\
\text { requirements. }\end{array}$ \\
\hline 48 & $\begin{array}{l}\text { 40) CFR } 265.1030 \\
\text { Subpart AA }\end{array}$ & Vessel Vents & No & No RPP facility has vessel vents. \\
\hline 49 & $\begin{array}{l}\text { 40 CFR } 265.1080 \\
\text { Subpart CC }\end{array}$ & $\begin{array}{l}\text { Air Emission } \\
\text { Standards for tanks, } \\
\text { surface } \\
\text { impoundments, and } \\
\text { containers }\end{array}$ & No & $\begin{array}{l}\text { Currently mixed waste is exempt from this } \\
\text { regulation. For waste not containing } \\
\text { radionuclides, it might become necessary to } \\
\text { measure the total organic concentration of the } \\
\text { waste in support of air emission regulations. }\end{array}$ \\
\hline 50 & $\begin{array}{l}40 \text { CFR } 265.1100 \\
\text { Subpart DD }\end{array}$ & $\begin{array}{l}\text { Containment } \\
\text { Buildings }\end{array}$ & No & $\begin{array}{l}\text { No additional analyses are needed to address } \\
\text { these issues. }\end{array}$ \\
\hline 51 & & $\begin{array}{c}\text { Complete Resource } \\
\text { Conservation and } \\
\text { Recovery Act of } 1976 \\
\text { Analysis }\end{array}$ & No & $\begin{array}{l}\text { For new incoming waste, the latest waste } \\
\text { profile that must be provided to tank farms } \\
\text { includes a full certification as to whether the } \\
\text { waste contains or does not contain land } \\
\text { disposal restriction (LDR) materials. This } \\
\text { profile is subject to verification by analyses } \\
\text { before the waste enters the tanks. } \\
\text { For the waste placed in the tanks in the past, } \\
\text { (i.e., legacy waste), the issues of LDR, and } \\
\text { universal treatment standard compounds has } \\
\text { been evaluated in Wiemers et al. (1998). }\end{array}$ \\
\hline
\end{tabular}


HNF-SD-WM-DQO-025 Rev. 1

Table A-1. Regulations That May Require Analyses. (5 Sheets)

\begin{tabular}{|c|c|c|c|c|}
\hline lten & Regulatory oriter & 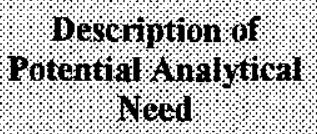 & $\begin{array}{l}\text { Additionilt: } \\
\text { inalyeis. }\end{array}$ & Raronale \\
\hline 52 & $\begin{array}{l}40 \text { CFR 268.7(a) } \\
\text { 40 CFR 268.30(d) } \\
40 \text { CFR 268.31(d) } \\
40 \text { CFR 268.32(a) } \\
40 \text { CFR 268.33(e) } \\
\text { 40 CFR 268.32(f) } \\
40 \text { CFR 268.32(I) } \\
40 \text { CFR 268.40 }\end{array}$ & LDR & No & $\begin{array}{l}\text { It has been established that at least one of the } \\
\text { LDR constituents exceeds LDR limits, and } \\
\text { therefore, no further analysis for LDR is } \\
\text { required by RPP (Mulkey 1999). }\end{array}$ \\
\hline
\end{tabular}

\section{REFERENCES}

40 CFR 264, 1998, "Standards for Owners and Operators of Hazardous Waste Treatment, Storage and Disposal Facilities," Code of Federal Regulations, as amended.

40 CFR 265, 1998, "Interim Status Standards for Owners and Operators of Hazardous Waste Treatment, Storage and Disposal Facilities," Code of Federal Regulations, as amended.

40 CFR 268, 1998, "EPA Regulations on Land Disposal," Code of Federal Regulations, as amended.

Mulkey, C. H., 1998, Double-Shell Tank Waste Analysis Plan, WHC-SD-WM-EV-053, Rev. 5, Westinghouse Hanford Company, Richland, Washington.

Mulkey, C. H, 1999, email to M. S. Miller, K. M. Meier, and D. L. Banning, "Dangerous Waste Regulatory DQO," dated March 29, 1999, Lockheed Martin Hanford Corporation, Richland, Washington.

Mulkey, C. H, M. Miller, and L. Jackson, 1999, Data Quality Objectives for Tank Farms Waste Compatability Program, HNF-SD-WM-DQO-001, Rev. 3, Lockheed Martin Hanford Corporation, Richland, Washington.

Resource Conservation and Recovery Act of 1976, 42 U.S.C. 6901, et seq.

WAC 173-303, "Dangerous Waste Regulations," Washington Administrative Code, as amended.

Wiemers, K. D., M. E. Lerchen, M. Miller, and K. Meier, 1998, Regulatory Data Quality Objectives Supporting Tank Waste Remediation System Privatization Project, PNNL-12040, Rev. 0, Pacific Northwest National Laboratory, Richland, Washington. 
HNF-SD-WM-DQO-025 Rev. 1

This page intentionally left blank. 


\section{DISTRIBUTION SHEET}

\begin{tabular}{|c|c|c|c|c|c|}
\hline \multirow[t]{2}{*}{ To } & \multirow{2}{*}{\multicolumn{3}{|c|}{$\begin{array}{l}\text { From } \\
\text { Environmental Permits/Policy }\end{array}$}} & \multicolumn{2}{|l|}{ Page 1 of 1} \\
\hline & & & & \multicolumn{2}{|c|}{ Date $\quad 06 / 30 / 99$} \\
\hline \multicolumn{4}{|l|}{ Project Title/Work Order } & \multicolumn{2}{|c|}{ EDT No. $N / A$} \\
\hline \multicolumn{4}{|c|}{$\begin{array}{l}\text { HNF-SD-WM-DQ0-025, Rev. 1, "Data Quality Objectives for } \\
\text { Regulatory Requirements for Dangerous Waste Sampling and } \\
\text { Analysis" }\end{array}$} & \multicolumn{2}{|c|}{ ECN No. ECN-654983 } \\
\hline Name & MSIN & $\begin{array}{l}\text { Text } \\
\text { With } \\
\text { All } \\
\text { Attach. }\end{array}$ & Text Only & $\begin{array}{l}\text { Attach./ } \\
\text { Appendix } \\
\text { Only }\end{array}$ & $\begin{array}{l}\text { EOT/ECN } \\
\text { Only }\end{array}$ \\
\hline
\end{tabular}

Office of River Protection

L. A. Huffman

A. C. McKarns

R. R. McNulty

N. C. Welliver

DOE Reading Room

Fluor Daniel Hanford Corp.

L. E. Borneman

F. A. Ruck

W. E. Toebe

Lockheed Martin Hanford Corp.

W. L. Adams

D. J. Carrel1

M. L. Dexter

B. G. Erlandson

K. M. Hall

J. W. Hunt

D. J. McCain

C. H. Mulkey

G. A. Stanton

T.C.S.R.C.

Lockheed Martin Services, Inc.

Central Files

MACTEC

R. D. Potter

Pacific Northwest National Laboratory

M. E. Lerchen
A0-21 $\quad X$

A5-15 $\quad X$

A2-22 $\quad X$

$57-54$

H2-53

A3-03

H6-23

$\mathrm{H} 6-23$

S5-15

R1-51

R1-51

R1-51

R2-12

R2 -12

R2 - 12

R1-51

S7-01

R1-10

$x$
$X$
$X$
$X$
$x$

$x$

B1-07 X

R3-73 $X$

A0-21 $\quad X$ 